\title{
The Colossus of Rhodes: Its Height and Pedestal
}

\begin{abstract}
Robert B. Kebric ${ }^{*}$
This is one of several interrelated articles on the Colossus of Rhodes submitted to ATINER journals. No conclusive literary or archaeological evidence exists to demonstrate the exact height (or configuration) of the Colossus, one of the Seven Wonders of the Ancient World, or the nature of any pedestal on which the giant statue, the largest in the Greek world, was mounted. This study gathers together for the first time all the relevant ancient and modern evidence concerning these questions, offering fresh interpretations of the material and determining that the Colossus was at least 110 feet tall and stood on a three-tiered pedestal some fifty feet high-- a combined height of 160 feet. A related study printed in another ATINER journal on the Colossus' location, places the statue, a votive offering to Helios, God of the Sun and the island's patron deity, at the apex of the acropolis of Rhodes city among the island's other most sacred temples and monuments atop what is today known as Monte Smith. The latter, approaching a height of about 300 feet in antiquity, would have elevated the Colossus some 460 feet above the sea below and also made it an ideal light tower for vessels approaching and leaving Rhodes' five harbors. A number of photographs and illustrations complement the inquiry.
\end{abstract}

In another study, ${ }^{1}$ I concluded that the best location for the Colossus of Rhodes, one of the Seven Wonders of the Ancient World, was atop the sacred apex of the ancient Rhodian Acropolis on what is today known as Monte Smith. This inquiry reinforces that conclusion, but it is concerned primarily with the height of the Colossus and the pedestal on which it stood. While no exact figures are possible since nothing of the giant votive offering to Helios, patron deity of the island of Rhodes, remains, the most useful working numbers to be drawn from available evidence are a height for the statue of the Colossus of approximately 110 feet, and fifty feet for its pedestal: a total of 160 feet. When combined with an elevation of close to 300 feet for Monte Smith (which can only be approximated for ancient times), the Colossus in its entirety would probably have towered some 460 feet about sea level.

"Senior Professor of History (Retired), University of Louisville, USA.

1. Robert B. Kebric, "Lighting the Colossus of Rhodes: A Beacon by Day and Night," Athens Journal of Mediterranean Studies 5, no.1 (January 2019): 11-31, https://www.athens journals.gr/mediterranean/2019-5-1-2-Kebric.pdf; and Robert B. Kebric, "The Colossus of Rhodes: Some Observations about Its Location," Athens Journal of History (forthcoming), 2019. 


\section{Part I: The Statue}

Because of the various ideas about the height of the Colossus of Rhodes statue, most differing by only a few feet, this study will use the figure of 110 feet as a reasonable common denominator. This is slightly higher than most modern translations of figures given by Philo, Strabo, and Pliny (see below), the only remaining ancient sources on the subject, who all provide a similar height for the Colossus, standardized as 70 cubits. Likewise, the equivalent of that measure in modern terms has usually been 105 feet- based on an 18-inch cubit. However, standardization does not mean accuracy (see Figure 1 below), and, as others have previously noted, ${ }^{2}$ the actual height of the Colossus was probably higher. Nonetheless, 110 feet is a reasonable mean measure to use for the statue here, and it has also been used in other studies.

Figure 1. This "template" of human measurements from an actual building site in Ancient Greece is one of the few in existence today. It clearly demonstrates the "personal" quality of measurements for each project, probably including the Colossus-- and why, despite modern statements about standardization of measurements in ancient societies, it is impossible to calculate the latter's height accurately. Those for the Colossus may have been based on the physical characteristics of its sculptor, Chares, himself. The stone's figures are reproduced more clearly in the second graph (Archaeological Museum, Piraeus)
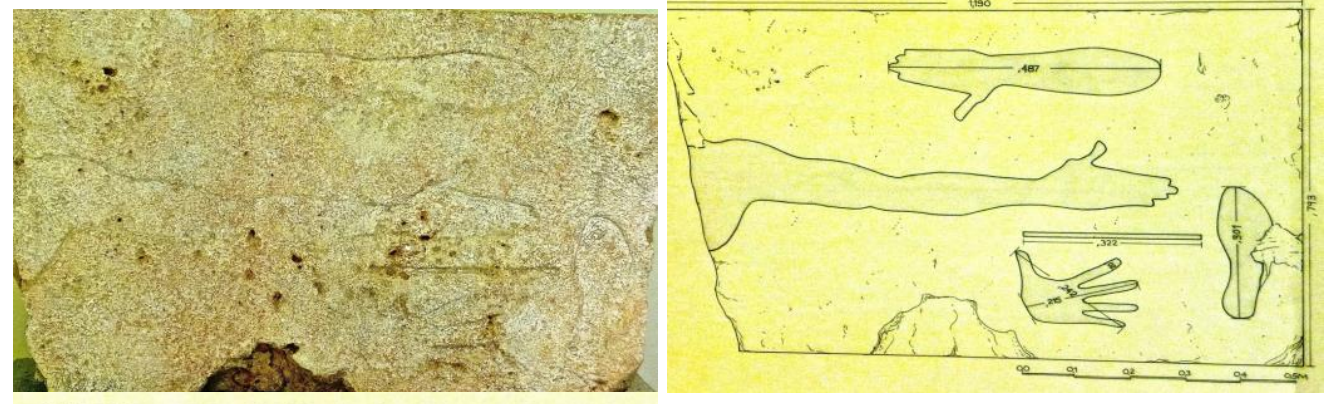

5352. Stone engraved with standard measurements, giving metrical units in half an orgyia ("span"), which is the span of the open arms, the pechys ("cubit") $(0,487 \mathrm{~m})$, the spithame (open palm) $(0,242 \mathrm{~m})$, and two standards of the foot $(0.0302 \mathrm{~m}$ and $0.322 \mathrm{~m}$ ). The second of these, in form of a rule, was used as a basis for the calculation of the cubit, the paim and the span. There is another relief with standard measurements and the span. There is another relief with standard measurements
in the Ashmolean Museum, Oxford, though this was probably a in the Ashmolean Museum, Oxford, though this was probably
dedication. Found bullt into a chapel on Salamis ( 4 th c. BC)

(a) Philo

2. Herbert Maryon, "The Colossus of Rhodes," The Journal of Hellenic Studies, Vol. 76 (1956): 73, for example, makes it "a little over 120 feet." See, also, e.g., Reynold Higgins, "The Colossus of Rhodes," in The Seven Wonders of the Ancient World, eds. Peter A Clayton \& Martin Price (New York: Barnes \& Noble, 1993), 130; cf., further, a listing of different heights in Matthew W. Dickie, "What Is a Kolossos and How Were Kolossoi Made in the Hellenistic Period?", Greek Roman \& Byzantine Studies (GRBS), vol. 37 (1996): 237-257, note 42, https://grbs.library.duke.edu/article/viewFile/2801/5855. 
Philo of Byzantium, certainly to be identified with the third century B.C. writer of engineering treatises, was the earliest of the three sources for the Colossus' height. He would have been alive at the time the giant statue was standing. Philo includes it as one of the "Wonders" in his widely-known De septem orbis spectaculis (4.1-6) and would not otherwise have mentioned it had it already fallen. He came to work at Alexandria in Egypt, and was active there during the last third of the third century B.C. ${ }^{3}$

While Philo could not have had any first-hand knowledge about the Colossus's construction, he certainly, judging from his close relations with Rhodes, must have seen it before it fell in an earthquake around 226 B.C. Philo's introduction to his essay on the "Wonders", so very brief for all the attention it has received, clearly implies that he had seen it when he writes (presumably including himself) that, only a "few have seen all of them for themselves." ${ }^{4}$ If he had not seen it but was, nonetheless, offering himself as an authority, he certainly expected his readers to be a tolerant lot-- willing to accept detailed descriptions from someone who knew little more, if any, than they did about the subject. It would also be difficult to understand why he would bother to take up the quill, busy as he was otherwise, to pen a work about spectacles had he not seen them all, himself, and wished to convey his own sense of wonder to a mixed audience that had little to no chance of ever seeing them. Clearly, he had been inspired to write.

Once published, Philo's booklet-- certainly inferior to his technical manuals, but not outside the interests he expresses in them-- became very popular and was often reproduced (no doubt, not always accurately). Living at Alexandria while people, like himself (many with families), were coming to the new capital from elsewhere in the Mediterranean, Philo simply may have wanted his pamphlet to be something of an armchair tourist brochure. It certainly has the tone of such. Through his descriptions, he could provide a literary treat for the mind. Perhaps he could help the recent arrivals adjust to their new environment by letting them know they were not as isolated as they might have first thought, and that there were amazing sights to see-- some close by, like the pyramids; others further afield at Rhodes, Halicarnassus, and Ephesus. Many new Alexandrians had undoubtedly come from the Greek peninsula and might already have seen Phidias' famous statue of Zeus; but probably only a few, many former soldiers, had ventured as far as the interior of the old Persian empire to Babylon - drawn there by their professions or by the many stories now circulating about Alexander

3. For Philo's date and his association with, and presence on, Rhodes, see E.W. Marsden's convincing study, Greek and Roman Artillery: Technical Treatises (Oxford: Oxford University Press, 1969; reprint, 1999), 7-9, 109 and note 8; cf., also, John \& Elizabeth Romer, The Seven Wonders of the World: A History of the Modern Imagination (London: Seven Dials, Cassell \& Co., 1995), 25-47, especially p. 36.

4. See Hugh Johnstone's translation in John and Elizabeth Romer, The Seven Wonders of the World: A History of the Modern Imagination (London: Seven Dials, Cassell \& Co., 1995), 230. 
the Great, their city's namesake, and by the fact Babylon was once the repository for his body. In fact, as previous studies have already noted, all of the Seven Wonders can be related in some way to Alexander. Interestingly, Philo does not include the Pharos at Alexandria in his list. Perhaps it was not fully complete at the time, or was not yet considered comparable with the others. Maybe it was because Philo thought there was no need to mention a local landmark that everyone could already see towering over the harbor at Alexandria.

The most realistic reason that Philo omitted the Pharos in his list of "Wonders" was that considering the state of "lighthouses" at the time the Pharos was built, most were little more than elevated platforms on which fires were placed to help guide mariners into port. Despite the fact that this was Alexandria, destined to become the greatest city in the Mediterranean world, in Philo's day it was still in a state of development. We are always in the habit of judging things from later images of what they looked like, and the same is undoubtedly true for the Pharos lighthouse. What it looked like when first built is unknown, but it certainly was not as grand as later illustrations make it to be - nor what modern romantic notions convey about its grandeur. The first meaningful insights about its appearance do not come until the Roman imperial period, beginning with the emperor, Domitian, when coins issued from the Alexandria mint depict it. Perhaps by deconstructing later Arabic descriptions of its ruins, we can surmise that it first was circular in shape before stronger outside walls encased it, and two more tiers raised its height to over 400 feet. It certainly was not so grand in Philo's time, probably just a more elaborate tower with a flaming beacon on top, as the

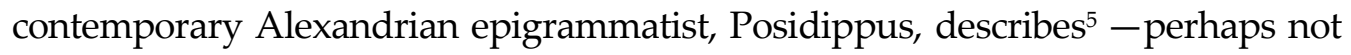
yet worthy of "Wonder" recognition.

To complete his own list of "Seven," Philo included the walls of Babylon and the Hanging Gardens at Babylon. Philo's living in the third century B.C., would assure the tradition that the Gardens did exist, and from what he describes, he had probably seen them, himself. However, it is odd that Philo gives no specific location for them in his work. It has always been assumed that they were in Babylon, but Philo does not say exactly where. No trace of the Hanging Gardens has been found among the ancient ruins of Babylon, leading some to suggest that they existed elsewhere-- but courses of rivers change, flooding some areas and/or leaving others to decay; natural disasters cover or alter what was once perfectly clear; systematic, purposeful total destruction can occur; deterioration through neglect can, too; and there could be other reasons that the site of the Gardens has not yet been discovered. There are, after all, no traces of the Colossus of Rhodes.

The Gardens may have been so famous that Philo did not feel he needed to give more specific information. Everyone knew where they were. He would have

5. A.S.F. Gow and D.L. Page, The Greek Anthology: Hellenistic Epigrams, (Cambridge: University Press, 1965), 11; C. Austin and G. Bastianini, Posidippi Pellaei Quae Supersunt Omnia (Milan: LED, Edizioni Universitarie di Lettere Economia Diritto, 2002), 115. 
known they were more than just some lingering romantic tradition. The Gardens were far more likely to have been located in Babylon than at the earlier Assyrian capital of Nineveh, as some have suggested. They would have attracted much less attention had they been anywhere else, "in so far as other sights," Philo relates, "can be seen just as much as these, but the admiration provoked for the Seven Wonders and for other sights is different." 6 Babylon was not Nineveh. It was Alexander's old capital - at which his body had lain for some time after his death, most assuredly, in a place equal to the man, himself. Such a place was within the grounds of the Hanging Gardens.

While at Alexandria, Philo also states that he frequently engaged in personal consultations with his counterparts on Rhodes. In his Belopoeica (51.10), he says,

We shall recount to you exactly what we discovered at Alexandria though much association with the craftsmen engaged in such matters and through intercourse with many master craftsmen in Rhodes, from whom we understood that the most efficient engines more or less conformed to the method we are about to describe. (Translation by Marsden)

This passage clearly indicates Philo's interest in what went on at Rhodes, one that was also shared by the Ptolemies who ruled Hellenistic Egypt. Ptolemy I is thought to have earned his epithet "Soter" from his rescue of Rhodes during its siege by Demetrius Poliorcetes-- the event that led to the building of the Colossus as a votive offering to Helios, the island's patron god. Some decades later, the most generous offer made by Ptolemy IV to rebuild the giant statue after its collapse in an earthquake around 226 B.C. reaffirmed Ptolemaic desire to remain involved at Rhodes. Since Philo, a technological expert, was living in Alexandria at the time, he may even have been dispatched as part of a team to make a preliminary survey of the damage before Ptolemy IV made his offer. If so, nothing ever came of it.

Because Philo was not old enough to have any personal knowledge about how the Colossus was built, what he did write could only have been speculative-based on what he, himself, saw, and what sources at Rhodes told him long after it had been completed. He did pose some questions about the Colossus in his small essay, but they are concerned more with its interior iron framework, which would have been completely covered at the time it was standing. It is not our interest, however, to enter into the drawn-out discussion over how the great statue was constructed--- although some pertinent details relating to Philo are not without interest.

While Philo's training was in applied mechanics-not colossal statues-he does show an interest in sculpture. At the beginning of his Belopoeica (50.5), he includes a comment that the renowned fifth century bronze sculptor, Polyclitus,

6. Johnstone's translation, in Romer, Seven Wonders, 230.

7. Marsden, Artillery, 109. 
had made about his own work: "that perfection was achieved gradually in the course of many calculations." Otherwise, careless small discrepancies could result in "a large total error at the end." Repeating Polyclitus' caution is clear indication of Philo's meticulousness in executing his own projects. He was not a careless technician-- and another passage indicates his expert sense of proportion, which also would have influenced his assessment of the Colossus:

For instance, the correct proportions of buildings could not possibly have been determined right from the start and without the benefit of previous experience, as is clear from the fact that the old builders were extremely unskillful, not only in general building, but also in shaping the individual parts. The progress to proper building was not the result of one chance experiment. Some of the individual parts, which were equally thick and straight, seemed not to be so, because the sight is deceived in such objects, taking no account of perspective. By experimentally adding to the bulk here and subtracting there, by tapering, and by conducting every possible test, they made them appear regular to the sight and quite symmetrical, for this was the aim in that craft. (Marsden) ${ }^{8}$

These observations about building houses, including proportion and perspective, are not entirely out of character with the analysis we find in Philo's account of the Colossus. The problem in the latter case, however - besides its brevity-- was that while Philo could admire the Colossus' Polyclitan "perfection" in form, he lived too long after its completion to know all "the many calculations" (literally and figuratively) that Chares of Lindos, builder of the Colossus, had been compelled to make during its actual construction. A similar problem had faced the creator of the Statue of Liberty, which is often compared to the Colossus of Rhodes. What had appeared perfectly acceptable to French sculptor, Auguste Bartholdi, when working with small scale models of the Liberty, did not work at full scale, and "each time the form was blown up visual corrections had to be made to compensate for the new effects of the old form at greatly enlarged scale - decisions that could only be entrusted to the sculptor himself." ${ }^{\prime 9}$ In his day, Chares would have experienced the same problem, and much of what he did "on the spot" was not recoverable. Even if it were, it was not preserved- an unfortunate fact of life during Philo's time that probably happened frequently and is clearly demonstrated elsewhere in his own work: When attempting to reproduce a "bronze-spring engine" invented by his immediate predecessor at Alexandria, Ctesibius, Philo discovered that "the constructional details had not been passed on" (67.25)--- lost even to "some of those who watched him [Ctesibius] inquisitively." The example does not say much for the continuity we might expect to find in the workshops of even the old masters. Undaunted, Philo and his colleagues determined not to lose the technology of a machine of

\footnotetext{
8. Ibid., 109.

9. Marvin Trachtenberg, The Statue of Liberty, (New York: Viking Press, 1976), 119.
} 
such "excellence." They followed Ctesibius' original design as far as they were able and augmented it with their own ideas about how to make it work. The result, according to Philo, was an engine somewhat different in design, but just as effective as (or better than) Ctesibius' original.

Surely, when Philo was trying to reconstruct just how Chares had proceeded in building the Colossus, he would have been confronted with the same kind of "lost" constructional details. Over the twelve-year period it reportedly took to finish the statue, there must have been many things forgotten a half century later. Philo would have followed the same procedure he describes that he had done with Ctesibius' engine- following Chares' design as best he could, and then augmenting it with his own ideas. It was also Philo's practice to construct small-scale models, the measurements of which were then converted proportionnately to the final working product (55.10ff.). One would think he would have applied the same methodology to his understanding of how Chares, who also based his finished work on small-scale models, had gone about constructing his Colossus.

Working from such models to construct colossal statues continued in Pliny's day. The latter provides some interesting information about one such model used by Zenodorus for Nero's Colossus at Rome. Pliny (d.79 A.D.) even says he had seen the model in Zenodorus' studio, "not only to admire the remarkable likeness of the clay model but also to marvel as the frame of quite small timbers which constituted the first stage of the work put in hand" (34.18.45-46). ${ }^{10}$ Pliny also says that the statue, (presuming still speaking of Nero's Colossus) showed how much the skill in bronze-founding had disappeared by his time, and seems to be saying that while Zenodorus was no less an artist than any of the old masters, that lack of knowledge caused him some hardship in completing his colossus - Nero was even ready to provide gold and silver, presumably in bulk form, to help complete the statue's outer skin.

It is not entirely clear what Pliny is saying here. If the old skill of bronzefounding had been lost and even metals like gold and silver were being offered by the emperor to complete it, of what was Nero's Colossus ultimately made? It has become regular practice to say it was "bronze," but perhaps this idea, reinforced by Fred Albertson's 2001 study, ${ }^{11}$ needs further review. What Pliny appears to be saying is that Zenodorus, a craftsman equal to past great ones, had to struggle to produce his colossal figures in the first century A.D., because the art of working in bronze had so deteriorated. In other words, the comments of Pliny, which Albertson apparently believes confirm Nero's Colossus was made of

10. Pliny, Natural History, ed. and trans. H. Rackham (Loeb Classical Library, Cambridge, Mass.: Harvard University Press, 1952; Reprint, 1995).

11. Fred C. Albertson, "Zenodorus's 'Colossus of Nero,'” in Memoirs of the American Academy in Rome, vol. 46, ed. Anthony Corbeill (The University of Michigan Press, 2001), 95-118. 
bronze, ${ }^{12}$ appear to be saying the exact opposite. For now, perhaps, a less definitive term, like "copper alloy," might be a better description for Nero's Colossus. Albertson's work is otherwise very useful for his discussion of Philo, the Colossus of Rhodes, and other relevant information, and all we can say is that Pliny's comments about the deterioration of bronze-working definitely affirm that the old way, the one used by Chares' to construct his bronze Colossus, had been lost.

A comment Pliny made in the same discussion about Zenodorusregarding an earlier colossal statue of Mercury the latter had fashioned in Gaul, that took ten years to complete- does have immediate application, because it is useful as a comparison to the one Pliny made about Chares taking twelve years (34.18.41) to complete his Colossus of Rhodes. If correct, it demonstrates just how long these giant works took to complete.

Ultimately, what Philo did write in his brief analysis about how Chares proceeded in building the Colossus of Rhodes, probably seemed workable to him; but, unlike in the case of his artillery models, the scale of the Colossus far exceeded anything in Philo's own experience-- he had no way of knowing whether or not he had correctly understood. Philo, of course, did not need to, because, unlike with the precise engines whose effectiveness he had to prove to members of his profession (and his patrons), he did not have to build a Colossus. His De septem was not a technical manual but an uncomplicated piece, probably turned out in his leisure and meant to entertain a wide audience-- and what he had come up with in his recap of the Colossus' construction only needed to have the "feel" of the real thing. He simply did not know if (and could not prove) what he described would actually work, and no one was going to build another colossus based on his musings. He, himself, was aware that his explanations were not always easy for others to grasp, observing in his description of another, unrelated, mechanical engine that, "Perhaps what we have said appears incredible to you, as it has to many others" (70.35). Three centuries later, Zenodorus, it appears, was in a position not unlike that of Philo when he was attempting to build his own colossus without a proper "blueprint." No one seems to have understood the process of the building of the Colossus of Rhodes exactly, and the recurring problems faced by later sculptors might at least lead us to view whatever detractors have said about Philo's comments in a more sympathetic light.

As for how close Philo ever got to seeing the Colossus while it was still standing is another question. If, as we assert, it stood atop Monte Smith at the summit of the Rhodian acropolis, access may have been restricted-- as was typical for sacred structures and votive offerings. This was a particularly large one, and caution, alone, would probably also dictate how far anyone without authorization could approach (especially if it were also a working lighthouse). Weather conditions could also be a problem. The Colossus most likely was within an enclosed precinct, so perhaps the best view of it - one that would also display it

12. Ibid., 97. 
in all its glory rising above everything else-- was from a distance. Nonetheless, since Philo was so well known among colleagues at Rhodes, he may have been allowed closer access, which might have provided some additional hints about how it had been constructed. He was certainly privy to some tradition about itbut, a half century after its construction, anyone of importance who might have provided more definitive answers was dead. The best he came away with was what had become the prevailing tradition among the Rhodians, packed with remembrances of what individuals had been "told by their fathers" --and whatever else Philo might have ascertained by his own observations.

Ultimately, the Romers ${ }^{13}$ have summed up the problems relating to exactly how the Colossus was constructed most sensibly:

The most important thing, however, is that there is no need to imagine that Chares used a single method of construction for his statue...It is difficult to imagine that Chares' Colossus did not also have different parts of it made in different ways; a colossal brazen statue such as the world had never seen, held together with good craftsmanship and with experience that reached back for millennia to the beginnings of history.

It is the height of the Colossus, not its construction method (which we leave to those like Ursula Vedder in her 2015 summary, "Was the Colossus of Rhodes Cast in Courses or in Large Sections?"14) that most concerns us here (although Vedder does go as high as 114 feet). Curiously, while we today would think anyone would first be attracted by the Colossus' height, Philo does not seem overly interested about how tall it was. In fact, he mentions it only in passing and seems more intent on confirming that the giant statue did, indeed, represent Helios-- and in the amount of bronze used in its construction. After it had fallen, he and other interested visitors may have been able to see it closer as it lay on the ground-- viewing, as Pliny later described, some of its pieces and inner structure. By that time, however, Philo's pamphlet on the "Wonders" had itself already become a piece of literary history, reaffirming the fame of the once great Colossus and apparently encouraging enough readers to travel great distances just to see the huge pile of rubble it had now become-- "sacred" as it might still be. Pliny confirms that they did.

Philo's booklet became the ancient version of the modern "bucket list" of must-sees for many travelers. Both Strabo and Pliny later agree with him about the Colossus' height, but neither mention Philo by name. That might at first seem

13. Romer, Seven Wonders, 39.

14. Ursula Vedder, "Was the Colossus of Rhodes Cast in Courses or in Large Sections?" in Artistry in Bronze: The Greeks and Their Legacy: XIX International Congress on Ancient Bronzes, eds. Jens M. Daehner et.al. (Los Angeles: The J. Paul Getty Museum and the Getty Conservation Institute, 2017), 21-27, http://www.getty.edu/publications/arti stryinbronze/downloads/DaehnerLapatinSpinelli_ArtistryinBronze.pdf. 
an important omission, but there really was no reason why either would have mentioned him since neither's comments were focused primarily on the giant statue. They certainly had read other accounts from authors, whom they also do not cite. By their times, the Colossus was only an interesting memory, and for Pliny's Roman audience, at least, the colossal statue (formerly) of Nero (18.45-46) was now the "big thing" attracting people's attention. The Colossus of Rhodes' once impressive height had probably become little more than a listing in an ancient equivalent of a "Facts on File," an arcane statistic educated persons of the day could cite at random-or use in satire, as Lucian did. Nonetheless, as our most contemporary reporter, Philo's statement that the Colossus was 70 cubits tall, equated here to 110 feet, is probably as definitive a measure as we are ever going to get.

\section{(b) Strabo}

Strabo (c. 64 B.C.- after 21 A.D.) gave his source of information for the 70 cubit height of the Colossus as the "author of an iambic verse," an obscure reference suggesting to many that it came from the original dedication on the Colossus. ${ }^{15}$ Considering Strabo's interests and opportunities to do so, there is no reason to believe that he had not seen the remains of the Colossus. He was from that part of the world, having been born in Pontus on the southern shore of the Black Sea. He also says (2.5.11) that he had traveled widely and that no one who had written geography had journeyed over a wider extent of countries than he had. Because Strabo spent an extended stay in Egypt (as Philo had done earlier), it is likely he would have traveled through Rhodes to get to Alexandria. Perhaps he had also done so as a stop on one of his visits to Rome. He did know that when one arrived by sea at Rhodes City, it is in a harbor on the eastern side, which likely comes from his personal knowledge. Whatever the case, his many travels certainly would have taken him to Rhodes, probably several times, which he thoroughly describes in his Geography. ${ }^{16}$

Two other items are revealing in respect to Strabo's presence at Rhodes. As a youth, he studied under Aristodemus of Nysa (14.1.48), who, at the time, Strabo says, was "in his extreme old age." Strabo had his "entire course" with Aristodemus at Nysa-- but also mentions that "my teacher" had another school at Rhodes and traveled between the two. Because he indicates a long tenure with

15. Cf. Dickie, What Is a Kolossos and How Were Kolossoi Made in the Hellenistic Period, 253; also, Alexander Dale, "Lyric Epigrams in Meleager's Garland, the Anthologia Palatina, and the Anthologia Planudea," Greek Roman \& Byzantine Studies (GRBS), no. 50 (2010): note 53, https://grbs.library.duke.edu/article/viewFile/1461/1551.

16. Strabo, The Geography of Strabo, ed. and trans. Leonard Horace Jones (Loeb Classical Library, Cambridge, Mass.: Harvard University Press, 1960). https://archive.org/ details/Strabo08Geography17AndIndex. 
Aristodemus-- and the latter would have to have traveled to Rhodes to teach at regular intervals if he wished to keep any students-- Strabo would necessarily have to have accompanied the old man. Otherwise, it would have been his own education that would suffer. It was also not unusual for such extended relationships between student and teacher to become more personal and reciprocal. There are a number of examples, especially from Roman times (e.g. Brutus), wherein teachers became life-long friends and advisors to former students-- and, because Aristodemus was so old, the companionship of a bright, young pupil like Strabo at both Nysa and Rhodes would have provided welcome comfort and support.

Strabo's statement at the beginning of his Geography (1.1.23) about how readers should judge the merits of his work is also interesting. He says they should look at it as they would the completed colossal works of a sculptor-- and not decide its worth from a minute inspection of random parts of the narrative. They should "look principally for perfection" in the whole of his Geography, the proportions of which most readers would agree were colossal. Strabo's comparison of his work to a colossal statue is a striking parallel by itself, especially from one who was not a sculptor but a geographer-- but his "whole instead of the parts" analogy is incredibly close to what one might expect from an individual who had actually seen the pieces of the Colossus of Rhodes, the greatest colossal statue of its time, lying scattered imperfectly on the ground. Perhaps as a boy, Strabo had heard nothing but positive things about the beauty of the Colossus - but after seeing it fallen in pieces, it no longer exhibited the "perfection" it once did as a whole. A passage from Lucian may help recapture something about how Strabo may earlier have felt about the great statue. The second century A.D. Roman satirist has the Colossus, himself, tell Zeus, "Rhodes...decided to make me on this enormous overblown scale," but, "in spite of my size, I'm very well done; I have artistic quality." 17 The fallen colossus no longer had "artistic quality."

Strabo may have been so discouraged when he first saw the scattered remains of the once glorious statue that he remembered the unhappy moment, later employing it as an analogy for readers of his own Geography: Do not look at the pieces but always view a work in its entirety. It may also have been on an early visit to Rhodes that Strabo first learned of the dedicatory verse that had mentioned the statue's impressive height of near 110 feet.

\section{(c) Pliny the Elder}

Whether or not Pliny the Elder (23-79 A.D.) had actually been to Rhodes and seen the remains of the Colossus he describes cannot be known. It would

17. Lucian of Samosata, "Tragopodagra," in Selected Satires of Lucian, ed. and trans. Lionel Casson (New York: Norton Library, 1968), 11. 
certainly seem likely because of the scope of his curiosity (which contributed to his death in the 79 A.D. eruption of Mt. Vesuvius, just a few years after he had recorded his comments about the Colossus), and because of his official functions as a Roman magistrate. The latter caused him to travel extensively, mostly in Germany and Spain. His description of the pieces of the Colossus lying on the ground (34.18.41), however, appears to have been derived from personal conversations with-- or gleaned from the writings of-- a fellow magistrate, C. Licinius Mucianus. Mucianus' presence in the east allowed him access to the most famous tourist attractions, a special interest of his, and there is probably no reason to believe that Pliny did not base his comments about the Colossus and other statuary on Rhodes (34.17.36) on Mucinaus' observations. ${ }^{18}$ Mucianus would, therefore, most probably have been Pliny's source for the Colossus' height of 70 cubits.

In his description of the fallen giant, Pliny records that the Colossus' fingers were bigger than most statues, and its thumb (was there only one thumb fashioned in the round - or that had survived?) was so large that most people could not encircle it with their arms. He also states that there were huge cavities in the Colossus' torso, where limbs had broken off, and one could see the stones inside that had been placed to steady the Colossus while it was standing. In his description, Pliny has curiously overlooked the supports of the iron frame interior, which, together with the stones, had helped hold the giant statue together. The framework is one aspect of the statue's complex inner construction about which Philo is adamant in his discussion of the Colossus. Philo was an accomplished engineer. Ironwork was a tradition on Rhodes (Strabo 14.2.7), and Philo had been in the arsenals on Rhodes, where he had visited colleagues working iron who knew of his interest in the Colossus. They would have passed on to Philo whatever they knew about the tradition of the iron used in the statue's construction. It was something of which they would have been proud. Philo may even have been allowed, as a professional courtesy, a look Inside the Colossus by those who maintained its interior. ${ }^{19}$ In his brief discussion of the Colossus, Philo leaves a description: "the horizontal bars exhibit hammer-work in the Cyclopean fashion" and muses further, "What kind of fire-tongs were used, what size were

18. T.F. Caldwell's very thorough recent Master's Thesis states: “The fragments [in Pliny] relating to the island of Rhodes could be derived from Mucianus' personal investigations...." However, Caldwell also cautions, "it is also possible that [Emperor] Titus served as [Mucianus'] source of information for the number of statues Rhodes..." [Thomas Francis Caldwell, "The Career of Licinius Mucianus," (Master's Thesis, University of Melbourne, 2015): 44. https://minerva-access.unimelb.edu.au/bitstream/ handle/11343/91093/Thomas_Caldwell_MA_Thesis.pdf?sequence=1\&isAllowed=y].

19. Just as my wife and I, by way of example, arrived unannounced some decades ago at the newly-discovered and closed-to-the-public, Tomb of King Philip of Macedon at Vergina, and were allowed the courtesy of an impromptu examination of the site by Professor Andronikos' thoughtful assistants. 
the bases of the anvils, with what workforce was such a width of poles forged?"20 Yet, Pliny is silent about its interior framework of iron "poles" that Philo had praised.

Some inside structure of iron poles or bars, as Philo noted, necessarily held the stones in place: "The artist [Chares] secured [the Colossus] from the inside with iron frames and squared blocks of stone." The latter could not have just been stacked loosely inside, if for no other reason than Rhodes was in earthquake country and the blocks would shift, possibly throwing the statue over. It is just possible that during the fatal earthquake of c.226 B.C., a large number of stones broke loose from the iron frame holding them and radically shifted the Colossus' weight. The Colossus' collapse would have been a singular event. Philo's description states that the stones were held in place-not loose-- and there is no reason to doubt an expert engineer, so familiar with the building techniques of his day.

Chares, too, already knew from his master Lysippus' work that colossal statues needed to be reinforced to protect them from natural threats (e.g. Pliny's remark [34.17.40] about Lysippus' 60-foot statue of Zeus at Tarentum, that was so well-balanced it could not be dislodged, either by human or natural force). If for no other reason, there would have to have been an iron frame inside the Colossus to hold stones in place so that workmen could move freely about the statue's interior to service and repair it on a routine basis: Some remains of the iron frame(s) should have been visible among the massive remains of stones. There is no way to explain Pliny's omission, although the reason for the missing iron may be simple Rhodian economics. It could hardly have been "cost effective" to leave the bronze pieces of the Colossus lying about, which the tradition, at least, attributed to an oracular caution to leave the sacred bronze remains where they fell. If that were indeed the explanation for why the bronze was not removed, it may not have applied to the iron frame inside-- a utilitarian structure that had never been visible from the outside, anyway, but was still worth a lot of money. The value of so much "wasted" metal that could be "recycled" would have been phenomenal. It is not unreasonable to suggest that the Rhodians did, indeed, "mine" the iron over the years through the openings in the colossal torso to use or sell elsewhere.

If, as Pliny observes, the Colossus' torso still laid virtually intact on the ground with stones visible through large cavities in its body; and, if his failure to mention any traces of the iron interior framework is an indication it had been removed - then that would be a compelling sign that the "skin" of the torso had been cast, as Philo suggests, rather than made from individual bronze "sheets." Otherwise, the "corpse" of the Colossus, with little left of its interior frame to keep its shape, would have collapsed in upon itself from its own weight while lying centuries on the ground. It apparently did not.

20. Johnstone's translation, in Romer, Seven Wonders, 232. 
Pliny leaves some detail that may be useful in reconstructing how the remains of the fallen Colossus were laid out. It was a votive offering and its pieces still had sacred significance, so it seems somewhat offensive that visitors were allowed to satisfy their curiosity about parts of the statue in what would seem a rather profane, "touristy" way. Perhaps to avoid what had undoubtedly become an immediate nuisance for Rhodian authorities, a perimeter wall restricted access to the main torso of the Colossus - a delineated sacred area, above which the gaping holes and stones inside the giant statue could still be seen. One would also think some such barrier would be necessary to prevent animals from seeking shelter in the ruins. The damage caused by birds, always an architectural pest, mice (e.g. Lucian's satirical comment [Trag. 8] ${ }^{21}$ about large statues supported inside by wooden frames becoming home to hordes of mice), as well as insects over the centuries can only be guessed-- and just maintaining the integrity of whatever metal survived would have been a persistent problem. Allowing general access to the entire remains could be very dangerous, and theft would also have been a concern. Perhaps the thumb and a finger or two of the Colossus that Pliny described were on display in an adjacent but separate area, where a few interesting pieces from the Colossus were arranged. It would have been rather difficult for visitors to try to place their arms completely around the giant thumb if it were lying flat on the ground. If the pieces were mounted on raised supports slightly above the ground, however, then at least the story becomes more credible.

The Statue of Liberty, which has frequently been compared with the Colossus and whose designer, Auguste Bartholdi, had Chares' "Wonder of the World" in mind while fashioning it, may also be useful in helping determine something about the Colossus' size. While the height of the Statue of Liberty is routinely given as 305 feet, the statistic always includes her pedestal. Liberty, herself, stands only 151 feet, less than half that total-- and this measurement also includes the torch rising high above her head. If she is measured only from heel to head top, her height is reduced to 111 feet, about the same size as the Colossus. What is also revealing is that Liberty's index finger is just over 8 feet long, and the middle joint of that same finger has a circumference of $3^{\prime} 6^{\prime \prime}$, which would compare favorably with Pliny's comments about the circumference of the Colossus' thumb. Pliny had also said that the Colossus' fingers were taller than most statues- and most of the statues about which he was speaking were probably in the 6-8-foot range.

While such comparisons are, of course, imprecise, it would still indicate that the Colossus was on a scale close to that of the Statue of Liberty. No sculptor can reproduce exactly the "perfection" of a small-scale clay model in a colossal statue because alterations have to be made during the actual construction process. The Liberty's copper skin of $2.5 \mathrm{~mm}$ is, by most modern estimates, thicker than that of the Colossus, which would complicate any estimates based on Pliny's description of the precise size Colossus' thumb and fingers. Nonetheless, such comparisons

21. Lucian, Tragopodagra, 8. 
are valuable, and are at least helpful in confirming a height of well over 100 feet for the Colossus.

The more pressing problem in attempting to determine the correct height for the Colossus, however, is not so much with the ancient figures being incorrect, as it is, as shown earlier, in the attempts to equate them with modern standards. By way of example, the Romers' essay on the Colossus renders Philo's cubit calculation for the Colossus' height as 120 feet (although their statement that the 12-year project would have risen at a rate of 6-8 feet a year would seem to result in a shorter Colossus). ${ }^{22}$ Varying ideas about what constituted a standard cubit in antiquity-- whether it be the length from elbow to wrist, or forearm to the small or middle finger (further complicated if an actual individual's [perhaps Chares, himself] body appendages were used) makes a precise calculation of the Colossus' height impossible.

There is also the added difficulty of not knowing whether the Colossus was measured from the soles of its feet to its shoulder, to its hairline - or to the very top of a radiant crown. So, too, it is also unclear whether either of the Colossus' arms extended above its head - and, if so, was this included in the ancient measurements. Nonetheless, when everything Philo, Strabo, and Pliny the Elder said about the Colossus of Rhodes is considered, 110 feet remains the most useful working number for its height. It certainly was no shorter.

\section{Part II: The Pedestal of the Colossus}

The height of any pedestal on which the Colossus once stood is nowhere so specifically stated as it is for the statue-- but modern estimates are about fifty-feet high, a height that would accommodate most of the problems associated with a 110-foot statue standing upon it. Philo is the only one of the three main sources who mentions anything about a base for the Colossus, saying it was "A base of white marble" and that "the soles of the [Colossus'] feet on the base were already at a greater height than other statues." 23

Philo gives no dimensions for the base, but it was substantial enough to have kept the Colossus' giant feet anchored in place when the catastrophic earthquake of c. 226 B.C. hit (by way of comparison, the Statue of Liberty's feet are 25-feet long). Since Strabo specifically states (14.2.5) that the huge statue broke at the knees when it fell, that could have happened only if the feet remained firmly attached, holding the Colossus in place up to its knees. It would also mean that the "base" of which Philo speaks was substantial-- not just a larger version of the standard slab or block plinth on which smaller statues were typically placed. Internal supports of iron (and/or stone) would necessarily have to have run up

22. Romer, Seven Wonders, 36.

23. Johnstone's translation, in Romer, Seven Wonders, 232. 
from a much larger and stronger pedestal below-- through the feet embedded in the white marble plinth, and to the knees, where the strain became too great. At that point, the adjoining independent metal framework (and stone reinforcement) within the Colossus, that connected the larger upper part of the statue to the lower supports at the knees, was not strong enough to keep it upright - and it bent and fell.

Chares would have been fully aware that the Colossus could not be held in place simply by embedding its feet in a larger version of a plinth - and the system he ultimately designed had to have been technologically sound to keep the statue upright. Earthquakes were, and still are, a fact of life at Rhodes. There must have been a number that shook the island over the 66-year lifespan of the Colossus, probably even while it was being constructed. That the Colossus survived as long as it did in such an environment would demonstrate that Chares had indeed employed - successfully so, until the fatal earthquake-- a system of firm supports in an enormous pedestal on which the Colossus stood. There would also have had to have been compensation for thermal and all other atmospheric stresses, as, indeed, the engineers for the Statue of Liberty, including the brilliant technician Gustave Eiffel who built the Eiffel Tower in Paris, had to consider for the metal used in its construction.

Presumably, the Colossus would have continued to stand if not for its weakness at the knees (a vulnerable pressure point for humans, as well). A lower system of supports continued to hold the Colossus firmly in place, while what proved to be the weaker upper internal frame did not. It is doubtful that this was a design flaw. Chares would certainly have foreseen the problem area at the knees and followed the practice of his mentor, Lysippus, who provided independent support(s) for his own colossal statues (Pliny 34.17.40). The Colossus, however, was almost twice the size of Lysippus' tallest statue. Chares was moving into unknown territory in respect to what could happen to such tall statues. He probably believed that he had taken every engineering precaution - but an earthquake of apparently unprecedented magnitude proved him wrong. What is clear is that the Colossus would have to have had a huge masonry pedestal (with a massive internal system of iron and stone anchors) to support it, and that Philo's reference to a white marble base in which the Colossus' feet were embedded is also accurate - but, structurally, what he described could only have been the Colossus' plinth and not its pedestal.

Some idea about the character of a pedestal for the Colossus has been revealed in a recent study related to an ancient earthquake "technology" utilized in buildings in the ancient Eastern Mediterranean world. Earthquakes were always on the mind of ancient engineers and the study published by A. Bayraktar 
et al., ${ }^{24}$ presents evidence to show such technology at work in surviving ancient structures from the same part of the world as Rhodes.

Whatever remains of these structures, some going back to the sixth century B.C., their survival after so long a time in better-than-might-be-expected condition appears to be the result of this technology. The study found consistent evidence in a variety of buildings to show that "three layers of orthostat stone, with no mortar between the layers, served to absorb earthquake waves, which are concentrated at the primary time causing less movement to be transferred to the superstructure." This "seismic resistance method" of three stone layers with no mortar, allowed the main earthquake shock waves to "play out" before hitting the structure mounted on top of the platform and destroying it. This simple technology appears to have become routinely employed in earthquake active environments, and there is no reason to suppose that it would not have been used in Chares' design of the pedestal for the Colossus. Of course, if the ground in front of the structure should shift or collapse, as the limestone cliff on which we maintain the Colossus originally stood on Monte Smith shows evidence of having done over the past centuries, nothing could prevent the statue from falling.

There is, then, enough conclusive evidence from structures contemporary with the Colossus to propose that its pedestal, too, was composed of three unmortared tiers of stone, declining in size as they rose, as illustrated in the accompanying Figure 2 below. This was accepted earthquake technology in antiquity, and Chares and his engineers, some most assuredly from Egyptian background, would have employed it in their planning for the Colossus. The Giza Pyramids were also constructed mostly of layers of limestone blocks - with no mortar. They have survived thousands of years of earth movements beneath them.

24. A. Bayraktar, H. Keypour, and A. Naderzadeh, "Application of Ancient Earthquake Resistant Method in Modern Construction Technology," in Proceedings of the 15 WCEEE, Lisbon (Portuguese Society of Seismic Engineering -SPES, 2012), 38: 3070930718, https://www.iitk.ac.in/nicee/wcee/article/WCEE2012_5773.pdf. 
Figure 2. A. Gabriel's Earlier Reconstruction ${ }^{25}$ of the Building Process for the Colossus. Few subsequent studies, if any, would agree with the posture of the Colossus, but, for illustrative purposes, his acceptance of a three-tier pedestal of about 50 feet, including a small base/plinth at the top like the one Philo described, is shown here. "Scaffolding" from Demetrius' Helepolis is also included in Gabriel's concept (see the discussion below).

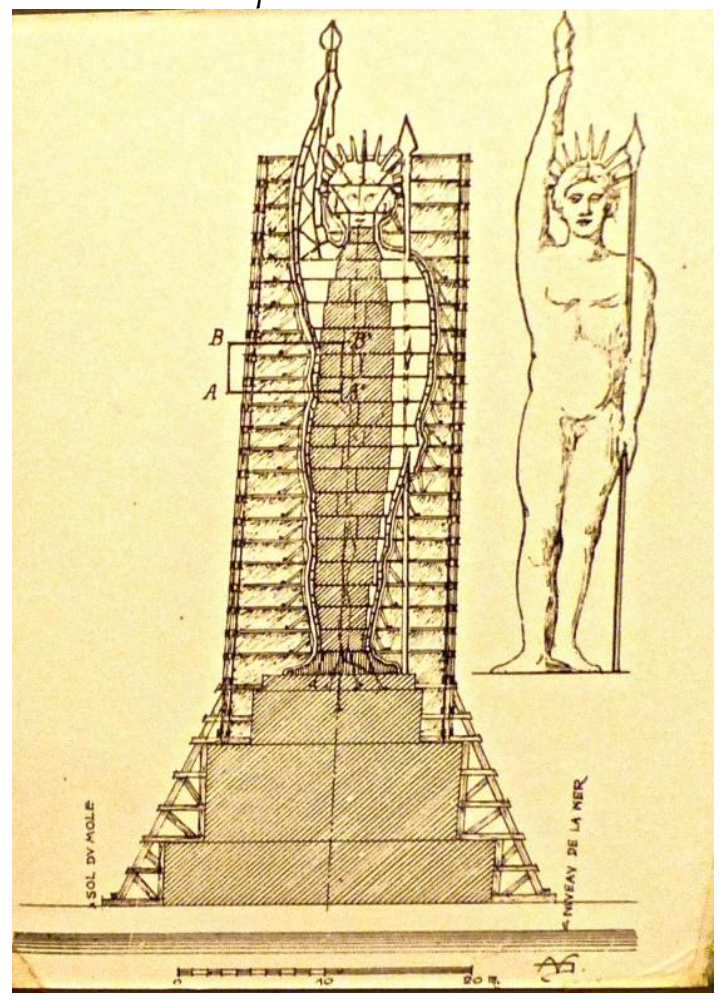

A three-tiered, fifty-foot high pedestal for the Colossus is not only contrary to Philo's previously discussed description for its base of white marble which we have determined could only relate to a large marble plinth in which the Colossus feet were embedded, but it is also controversial in another way. One would think it compulsory to have employed Rhodes' own native gray-blue marble, regularly quarried at Lartos, near Lindos, in any votive offering dedicated to its patron deity, Helios - this one for helping save the island from Demetrius' siege. In fact, one can imagine the citizenry's outcry, particularly at Lartos, if it were learned that white marble was being imported to use for the Colossus' pedestal instead of their island's native marble-- especially since it was routinely used on the island and widely exported, particularly for statue bases or pedestals. However, as explained earlier, Philo's "white marble base" can easily be reconciled if it were actually the plinth-- which rested atop the Colossus' much grander pedestal of

25. Albert Gabriel, "La Construction, L'Attitude et L'Emplacement du Colosse de Rhodes (The Construction, Attitude and Location of the Colossus of Rhodes)," Bulletin de Correspondance Hellénique, no. 56 (1932): 337. 
Rhodian gray-blue marble below. The famed Nike of Samothrace, now displayed in the Louvre Museum in Paris, provides a convenient illustration.

(a) The Nike of Samothrace

As seen in Figures 3a and 3b below, the well-known Nike of Samothrace's oared, ship-shaped base (and the additional elongated platform on which the latter sits) was made of Rhodian gray-blue marble. The marble was so well known on Rhodes for statue work that Philo could not have been referring to the Colossus' major pedestal when he mentions the "base of white marble" on which Chares "first set the feet of the Colossus up to the ankle-bones." He can only be alluding to the kind of white marble plinth, a large one in this case, that typically held a Greek statue's feet in place-- oftentimes resting on a larger pedestal beneath it. There are many surviving examples of ancient statues bases at Rhodes and elsewhere in which the imprints of the feet where full-size figures once stood are still fully visible.

Figure 3a. The Nike of Samothrace. We use it here only as an illustration for a base of Rhodian gray-blue marble to show what its color would have looked like if it formed the marble pedestal for the Colossus-- and, also, as an illustration of a "white base" on which the Nike immediately stands. The base is a modern addition, designed to elevate the statue for viewing purposes at the Louvre, but it is included to help visualize how the much grander white marble base for the Colossus may have appeared. This arrangement of statue, small white marble plinth, and grander Lartos marble pedestal is probably similar to what Philo was describing for the Colossus. See, also, Figure $3 b$

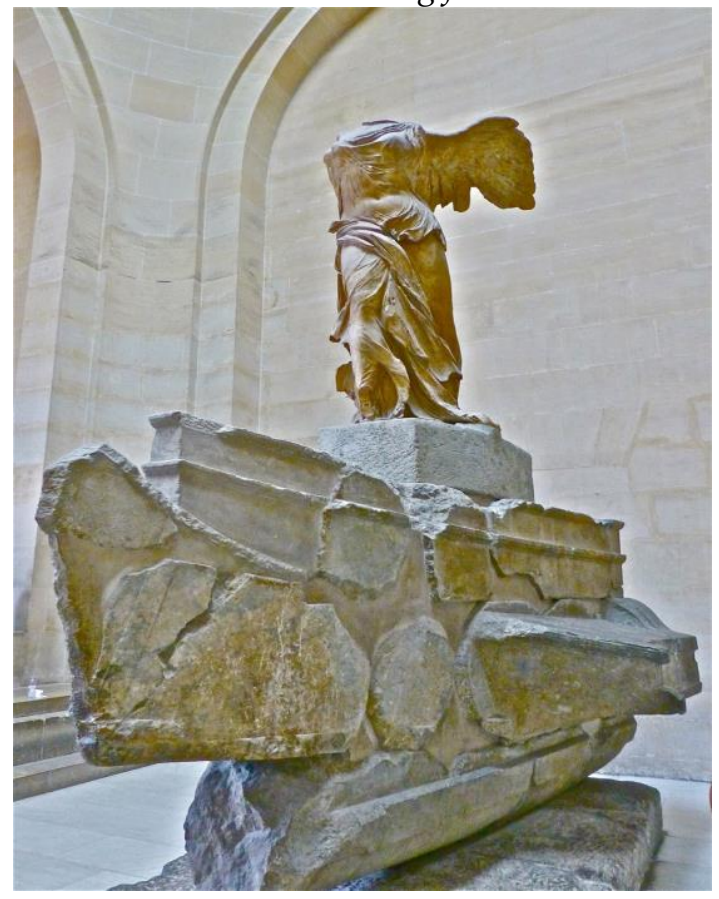


Figure $3 \mathbf{b}$. The white stone base, presumably marble, added by the Louvre staff for displaying the Nike of Samothrace atop the impressive Daru Staircase. Philo was probably speaking of something like this on a larger scale when he described "A base of white marble" in which the Colossus feet were embedded. It would have then rested on a significantly larger Rhodian gray-blue marble pedestal below it

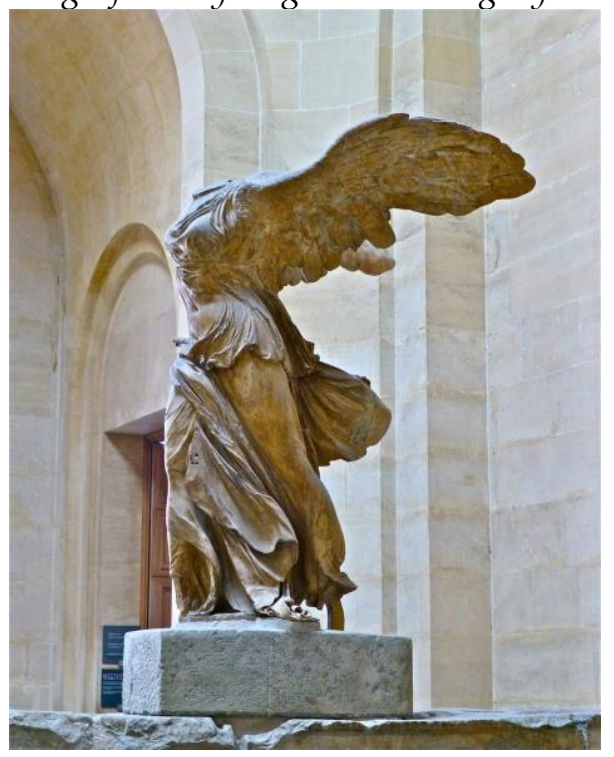

If Chares had not constructed the actual pedestal for the Colossus out of the native gray-blue marble, Helios' own unique stone (or at least faced the pedestal's exterior with it), not only would he have been insulting the island's inhabitants, but also the sun-god, himself, the patron of Rhodes, whose statue he was building. The contemporary Alexandrian epigrammatist, Posidippus, when speaking about the Colossus (AB 68), notes that the Rhodians were not satisfied with the height of Chares' giant statue and wanted him to make it twice as big. One can only imagine how they would have reacted if they learned that their own sculptor was purposely eschewing their native grayblue Lartos marble to build the pedestal for his Colossus in favor of generic white marble from elsewhere. The pedestal must, necessarily, have been made of Lartos marble.

There are sometimes white veins in Lartos marble, but it would have been a painstakingly difficult process to mine enough of it to provide a fifty-foot high "white" pedestal for the Colossus - if only for its facing. The only plausible interpretation for what Philo meant when he said, "A base of white marble was laid down," is that he was referring to a version of a standard-sized plinth that was enlarged proportionately to secure the Colossus' large feet. By way of comparison, the Statue of Liberty's feet, each 25-feet long, also stand on a separate "plinth" resting atop the $40 \times 40$-foot apex of a much larger pedestal below. What Philo described in his account of the Colossus was a white marble plinth-- on top 
of a fifty-foot, three-tiered pedestal of Lartos marble--- in which the Colossus' feet were embedded (as shown above in Figure 2).

The Colossus on its smaller white marble plinth interested Philo; the larger pedestal below did not. The latter was strictly utilitarian, a necessary but subordinate adjunct to the statue that formed no part of its artistic unity. To quote Marvin Trachtenberg in his Statue of Liberty, "Functionally, a pedestal is analogous to a picture frame: it isolates a work both physically and symbolically." 26 That does not mean that a pedestal cannot be decorative-- but, if it is, it cannot detract from what is ultimately displayed upon it. What caught Philo's eye stopped at the bottom of the white marble plinth which was still a part of the Colossus' artistic unity, reemphasizing his own sculptor's instincts in perspective and proportion. Today, people do not go to the Statue of Liberty to marvel at its 89-foot stone pedestal (and the 65-foot foundation it rests on). Liberty's pedestal is attractive as well as functional - but it is still only there to support and display the famous statue above it, which people do come to see. At night, it is Liberty-- not her pedestal-- that is fully illuminated.

Visually, how the Colossus was situated may ultimately have called to mind something like how the great quadriga of the nearby Mausoleum of Halicarnassus, another of the Seven Wonders, was displayed on a low "pedestal" set over a truncated pyramid below. ${ }^{27}$ Chares' white marble plinth for the Colossus was large enough to be noticed but small enough not to cause distraction or local controversy. The same enlarged white marble plinth would have provided a nice visual contrast between the shining colossal bronze statue above it and the grayblue pedestal below, faced with, or fully built of, the prized Rhodian marble.

The Nike of Samothrace is a useful example for this kind of visual contrast. Described as a "colossal work" in the Louvre Museum's own description of the famous Hellenistic statue, the Nike stands $18^{\prime} 3^{\prime \prime}$ atop a ship whose keel rests on its original flat, elongated base. The Nike, herself, is nine feet tall. Although heavily restored, it is the closest surviving sculpture we have to compare to the points we are making here: It is a "colossal" statue; gray-blue marble from Lartos, Rhodes, was used to make the ship-shaped pedestal on which Nike alights; and, while some believe the Nike portion of the sculpture may have been fashioned elsewhere, most consider the monument originally to have been an ex-voto offering by the people of Rhodes to commemorate an important naval victory in the early second century B.C. The statue also has a small white stone block upon which Nike stands, appearing to defy the strong winds blowing against her (always a threat to large statues like the Colossus) as she alights on the deck, separating her from the ship and providing a dramatic contrast. All these things are illustrated in the photos above.

26. Trachtenberg, Liberty, 151.

27. Ibid., 155. 
The white stone (presumably marble) base of the Nike of Samothrace is, however, a modern addition, placed there by the Louvre staff in 1934 to display the Nike, now at the top of the Grand Daru Staircase, to its full advantage. We are, nonetheless, using it here for illustrative purposes, because it clearly demonstrates the marked contrast the addition of the white base has made between the statue of Nike and the original gray-blue Rhodian marble of the ship below it. While not the sculptor's original intent, the Museum's "addition" probably followed as closely as possible what he would have done if faced with their problem in displaying it. If the white stone base had not been added by the Louvre, the bottom part of Nike, mounted at the top of the Staircase, would have been obscured to viewers. Positioning is always crucial to best show off a piece of sculpture.

Although altered for practical purposes, the Nike of Samothrace, still provides a striking visual representation of what Philo probably saw when he made his comment about the Colossus: A huge statue, whose feet were set on a small white plinth of marble which rested directly on (and was secured to) a much larger pedestal of Rhodian gray-blue marble. Using a little imagination, the Nike can also illustrate what impact the white marble addition would have if she were descending on what was only a generic, functional large pedestal of gray-white marble instead of the more interesting ship-shaped one. No one would even have noticed it because it would have had no role in the artistic unity of the piece. The viewer's eye would have been concentrated entirely on Nike, and, unavoidably, the white base on which her feet were inevitably alighting. That is how we suggest that Philo viewed the bronze Colossus of Rhodes, standing on the white marble base he describes. Coins that depict another colossal statue, this one of Apollo at Apollonia Pontica, ${ }^{28}$ show him standing on what appears to be something close to the kind of "base," or plinth, on which Philo said the Colossus stood and whose large feet were embedded (Figure 4). It also matches very well with the white stone base on which the Nike of Samothrace was set by modern restorers. For the Colossus, the "white marble base" would have been situated at the top of a fifty-foot pedestal.

28. Coins minted at Apollonia Pontica show full standing, frontal representations of their colossal statue of Apollo-- considerably shorter than the Colossus of Rhodes at 45feet and some two centuries earlier. They provide a splendid illustration of what the statue looked like standing on what is probably the same kind of "base of white marble" Philo had described for the Colossus. Specific photos of the coins (Stavri Topalov) may be viewed on-line, at, Ivan Dikov, "Bulgaria's Sozopol to Restore Ancient Statue of Apollo, 'Colossus of Apollonia Pontica', Not Unlike Greece's Plans to Rebuild Colossus of Rhodes,' Archaeology in Bulgaria (portal), January 5, 2016, http://archaeologyinbulgaria.co m/2016/01/05/bulgarias-sozopol-to-restore-ancient-statue-of-apollo-colossus-of-apolloniapontica-not-unlike-greeces-plans-to-rebuild-colossus-of-rhodes/. 
Figure 4. Feet of the colossal figure of Apollo, as represented on a coin minted at Apollonia Pontica, set on a base probably similar to the one Philo described for the Colossus of Rhodes

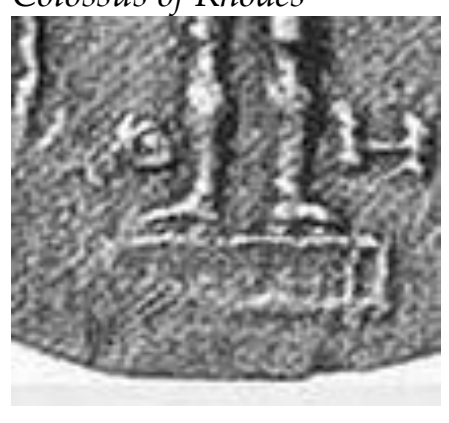

The actual three-tiered pedestal on which the Colossus did stand with its feet secured in the smaller white marble plinth at the top, had to have been a very deep and substantial one. Such a gigantic statue, especially one described by Philo as being built from the bottom up, would have to have had massive supports built into its heavy pedestal foundation. Even had a shaft(s) been excavated into the native limestone rock plateau of Monte Smith on Rhodes (none has been located), like the one that can still be seen today on the Acropolis in Athens designed to stabilize the Athena Promachos, such a shaft(s) could never have been deep enough to secure a bronze statue the size of the Colossus. It was about four times the height of the Promachos, which, comparatively speaking, stood on a very small pedestal, remains of which can still be seen. So, too, the Colossus never could have been held firmly in place merely by a small white marble plinth set atop a larger pedestal.

Instead, the pedestal undoubtedly had a core of heavy limestone, faced with the Rhodian gray-blue marble. Such facing procedures remained standard even at the time of the Statue of Liberty, in order to protect the inner structural stones from damage and to provide a more attractive finished appearance. It would also have been less expensive than fashioning the entire pedestal for the Colossus out of marble. Inside, giant iron "poles," and/or monolithic columns of limestone, sandstone, or granite (like those routinely produced in Egypt over the millennia), were embedded deep in its heavy stone core-- and they would have extended up through the pedestal, the white plinth, and the Colossus' feet to its knees. There, they were securely joined to the statue's upper iron and stone interior frame. 
Figure 5. A fanciful reconstruction (after Antonio Tempesta, 1608) of the moment that tradition, at least, says the Colossus was finally broken up by the Muslim conquerors of Rhodes and the bronze carted off to Syria, where a Jewish merchant from Edessa carried it away on 900 camels. Unfortunately, the illustration is of little value historically-although in later centuries, it is not inconceivable that the Colossus' "white base," still embedded with vestiges of its feet and lower legs, was moved and set up as a monument to its former glory in the town center at Rhodes. The artist follows Strabo's tradition that the statue broke off at the knees, but the base shown (and reconstructed with the Colossus atop it in the background) could never have supported a statue of that size. Also, it is more likely that during the Muslim presence on Rhodes, there may have been a few pieces of bronze still attributed (incorrectly) to the Colossus, but it was probably more some popular tradition still circulating about the once great statue that started an erroneous story about where the bronze had originated. By that date, 654 A.D., it is extremely unlikely any verifiable pieces of the statue still survived. That it took 900 camels to carry it off is also pure fantasy, especially since nothing is said about how the bronze was transported (at least, in the version related by Constantine Porphorygenitus) to Syria in the first place. If there is any truth at all to the story, it was probably bronze collected from Roman statues in Africa and everywhere else in the eastern Mediterranean that the Muslims had overrun, that was disposed of as an auction "lot." Any publicity about the bronze once belonging to the still well-known Colossus was a good "selling" point. There are several variants to the story, and the tradition that Muslims sold the pieces to a Jew is too glaring an irony in itself

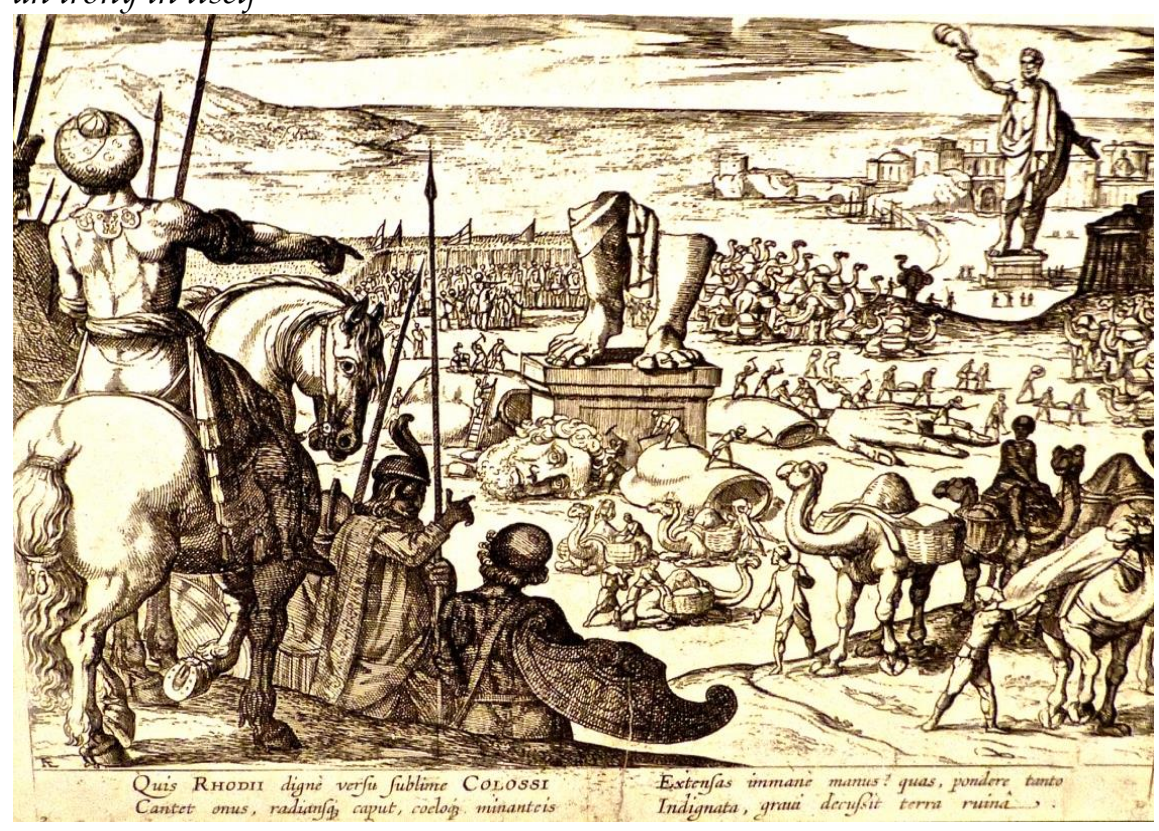

The procedure is much the same as that described for the Statue of Liberty, where the skeleton of the statue was so firmly attached to steel beams and girders 
embedded in its pedestal ${ }^{29}$ that it was said in jest (although it captures the general feeling of the designers) that if the monument ever turned over, the statue and pedestal would not separate as some might expect-- but the entire island on which it stood would turn over with it. The same feeling must have initially been attributed to how securely the Colossus had been "welded" to its pedestal, because every measure known to Chares and his staff of experts would have been employed to prevent its fall. To a large extent, their expertise was borne out: The Colossus stayed firmly in place on its pedestal up to and including the devastating earthquake of c.226 B.C. At that time, it was not the pedestal that failed but the structure above the statue's knees that did. The only way that could have happened was if all the measures that had been devised, both internally and externally, to keep the Colossus standing in place failed-- and the giant figure broke at the knees. It had to have been an earthquake beyond what Chares or anyone else had imagined.

Ironically, it may have been the same sturdy reinforcements Chares surely employed to safeguard the Colossus that contributed to its collapse. Even if he had used the three-tiered orthostatic earthquake platform system, which seems certain, the support columns embedded in the pedestal may have equally served as conductors, and the shock waves from this particular earthquake, instead of being dissipated, traveled straight up the supports to violently shake the statue and cause it to break at the weaker knee joints. It was the exact point in the statue's construction where the stronger pedestal reinforcements ended, and the Colossus' secondary iron and stone interior framework began.

\section{(b) The Walls of Rhodes}

Had the Colossus been standing at the time of Demetrius Poliorcetes' siege of Rhodes, its "knee problems" would not have mattered. The Rhodians had not been expecting such a devastating attack and were not prepared when it did happen. It is fair to say that, while precautions against earthquakes may have been taken, they would not have foreseen what could happen to a statue the size of the Colossus during war-- nor taken proper precautions to protect it. The Colossus would have been demolished by the direct fire of Demetrius' artillery. Who knows how many other "colossal" and regular-sized sculptures were actually destroyed during Demetrius' siege had they not been protected or temporarily stored-- like the bronzes unexpectedly recovered at Piraeus in 1959 that had been hidden during Sulla's siege of the Athens in 87 B.C. (and then forgotten) in secret "passages," like the ones Strabo describes at Rhodes (14.5). Later, when the Colossus was built, it could not be directly exposed to enemy missiles if the city were attacked again-- and, considering the militaristic atmosphere of the day, that was a realistic possibility. Anywhere the Colossus

29. Trachtenberg, Liberty, 142-143, Figure 83. 
was placed, at the very least it had to be protected behind the city's great walls. It also had to rise high enough above them to be seen in its entirety. Consequently, it is only logical that the pedestal on which it stood had to be at least as tall as the city walls. Perhaps, then, the walls of Rhodes will provide us with the best estimate of the height of the Colossus' pedestal.

It would only seem prudent that wherever the Colossus was placed, considering what had recently occurred with Demetrius' assault on the city, especially the harbors, the largest statue ever built in the Greek world would have the protection of the newly rebuilt walls. The same caution needed to be exercised if only to protect Helios' giant image from the frequent natural "assaults" that plagued the island. Nothing would be gained from building the pedestal of the statue into the new wall, itself. It might stabilize the Colossus' foundations, but it would still leave it open to a frontal assault by both man and nature and would certainly be less aesthetic in appearance. That being the case, two other alternatives come to mind: The Colossus was located behind the city walls, close enough to be protected by them but standing independently on its pedestal in the open; or, it could have stood in an enclosed precinct or sanctuary attached to the wall, ultimately enclosing it on all sides but with access gates (something like the remains of forts we still see along Hadrian's Wall in England). In fact, like the situation for the Statue of Liberty, it may have been built within the enclosure of an already existing fortress. The Liberty was built on Bedloe's Island directly on old Fort Wood, already permanently ensconced there and whose star-shaped bastions had to be incorporated in the final design of its pedestal.

An existing fortress, or fortress-like enclosure, may also have been involved in the Colossus' construction. Long after Monte Smith had served as the Rhodian acropolis, it had been a British observation post during the Napoleonic War, taking its name from Admiral Sir William Sidney Smith; and during World War II, the Italians had gun emplacements there in what appears, from allied reconnaissance photos, to be a fortress. High places in the earliest days of Ancient Greek communities were fortresses for protection, as well as religious centers. Usually, as the times became better, people moved down from the heights of their acropolises. Urban centers developed below them, and the acropolises continued to be sanctuaries for the city's gods. Since Monte Smith was undeniably a most strategic location and site of the acropolis of Rhodes, the suggestion that it also continued to serve as a protective fortress atop the heights of the city overlooking the main sea approaches to the city, is not just a suggestion - but an inevitable outcome. Thus, there could well have been a fortress (or more than one) located along the western high walls on the edge of Monte Smith that became less important with the subsequent reinforcement of the new city walls of Rhodes and whose new function became serving as a walled precinct for the Colossus. This would, arguably, be a natural evolution of such a venerable site. Whatever the case, the second of the above suggestions, accords best with all the requirements needed to build, protect, and maintain the colossal monument - and, also, with 
its role as a lighthouse, which it has all the appearance of being (discussed at length in another study).

With walls enclosing it all around and gates providing access into and out of the interior, the Colossus would have stood on its pedestal in the middle of a large, open precinct on the spacious heights of Monte Smith (perhaps not unlike Suetonius' description about how Nero's colossus was originally to be displayed in a large vestibule of Nero's Domus Aurea) - near to, but separate from, the large Temple of Athena and Zeus, the largest on the island, and other religious structures in the immediate vicinity. Built into these walls (of appropriate thickness) could also be quarters for the large number of men constantly needed to service and maintain the Colossus (like the barracks Roman sailors apparently lived in near the Colosseum to deploy its Velarium and attend to it otherwise). Defensive towers could also double as housings for the high-standing service equipment that would be needed to service and repair the 160-foot Colossus on its pedestal. These must have included transformed siege towers of Demetrius, which were the only available engines at the time capable of serving all the needs of the giant statue, both inside and out (see discussion below). It had to be maintained on a regular basis. A separate shrine dedicated to Helios could also have been present - unless the entire complex were already viewed as such. As a lighthouse, the Colossus could also be run daily, and its probable sun-reflecting mirror(s) polished and serviced from such an enclosure-- its fiery night beacon(s), most likely fueled with pine-based wood from the copious forests of Rhodes, regularly supplied. In such a compound, everything would have been provided to meet the Colossus' needs. The question remains, however: How tall were the walls of Rhodes?

While ancient writers, including Strabo, speak glowingly about the great walls of Rhodes, no one mentions their height. In fact, it is just as difficult to discover mention of wall heights at other cities around the ancient Greek world. The walls of Rhodes City were destroyed, often by earthquakes, and rebuilt stronger on several occasions, so one would think somebody would have mentioned how high they rose - if only as a matter of pride. The walls would, naturally, have varied in size depending on their particular location around the city's perimeter, and there were also numerous towers that were higher than the walls. Even the display in the archaeological room of the Grand Master's Palace within the medieval walls at Rhodes that highlights the walls, provides only a note about the width of the base of a section of the ancient wall: 4.2 meters, or about 14 feet. It is not much to go on, but, proportionately, a base that thick would immediately eliminate 10- or 15-foot walls- probably even twenty. One does not build a wall thick enough to repel damage to its bottom from offensive machines only to make its height woefully inadequate from attack by towering siege machines. Twenty-five feet is probably the minimal height. That seems to be reasonable because it appears to be the average height from which the lower drawbridge of a typical 90 -foot siege engine of the period crossed over to an 
opposing wall. There was no reason to employ a drawbridge at this height if it were not going to provide its soldiers access to a wall of similar height. The second drawbridge on the same siege engine, designed for attacking the towers of a city wall, comes in twenty feet higher, at 45 feet. Both drawbridges were slightly higher than their targets so that they would come to rest atop the city walls and towers. These numbers are the result of E.W. Marsden's careful study of siege craft, in his work on Greek and Roman Artillery, ${ }^{30}$ and are as definitive as the evidence allows.

Thus, the drawbridge levels of a typical siege engine of the day would put the tallest walls and towers at Rhodes in the 25-45-foot range at the time of Demetrius' siege. Afterward, when the walls were restored, everything indicates they were made even taller: The earlier walls had been inadequate to stop Demetrius, and if Ptolemy had not interceded, the city probably would have fallen. It was not a mistake the Rhodians would make again, and when the Colossus was built, the walls must have been in the 30-50 feet range. Hence, the Colossus' pedestal would have to have stood at least fifty feet high for the giant statue to be seen in its entirety above the new walls. Otherwise, the lower part of the Colossus would have been entirely obscured.

A century earlier, Dionysius of Syracuse, whose military innovations were legendary, protected his own city with the fortress of Euryalus, including the most up-to-date defenses. It can probably safely be said that his wall towers became the standard from which all subsequent designers based their own defenses at other cities, Rhodes included. The towers (and walls) were specifically designed for the military contingencies of the day, which included towers as high as five stories, containing appropriate artillery at all levels. Archaeological evidence indicates the towers were purposefully squared and as high as fifty-feet. This also "squares" well with what has been described here for the walls of Rhodes-- and there is no better evidence to reinforce it. ${ }^{31}$

Demetrius' Helepolis, the tallest and most famous of his siege engines, ${ }^{32}$ was significantly higher than even the new walls at Rhodes - by almost 100 feet. There were not, of course (nor were there ever going to be), any city walls nine stories high or 144-feet tall-- but part of the reason for the size of the Helepolis was intimidation. It is not described as having any drawbridges because attempting to deploy them at such a height would probably have made it top heavy - and it would fall over. Its primary function in battle appears to have been to fire missiles over the main city walls and beyond any additional interior walls, like those the Rhodians had constructed, to the more vulnerable areas of the city behind them.

30. Marsden, Artillery, vi; 87, diagram 3; and 89, note 36.

31. Peter Connolly, Greece and Rome at War (1981; Reprinted with revisions, London: Green Hill Books, 1998), 286-290. F.W. Walbank, and H.H. Scullard previously acknowledged Connolly's significant expertise on the ancient military.

32. Marsden, Artillery, 84, note 24. 
However, the Helepolis never appears to have been successfully utilized, and Demetrius, apparently, by common agreement with the Rhodians, left it behind when he ended the siege and departed.

It would not do if the formidable Helepolis, a "colossus" in its own right among the sea of siege towers constructed for Hellenistic warfare, was not surpassed in height by the Colossus-- a commemorative votive offering to Helios constructed in honor of the terrible machine's own defeat. Also, the Helepolis' remnants were traditionally taken into the city and placed on display (Vitruvius, de Architectura, 10). The Rhodians had ample opportunity to examine the weapon from top to bottom-- and, almost 90 years ago, Albert Gabriel offered the very cogent suggestion that whatever technical and engineering lessons Chares had learned from his own examination of the Helepolis-- as well as its physical remains-- were employed during his construction of the Colossus. ${ }^{33}$ Gabriel's reconstruction of the Colossus in Figure 2 reflects his ideas.

There is no good reason to question the idea that the Helepolis-- or, for that matter, any other siege engines left by Demetrius-- was used during the construction of the Colossus and that it and the other remaining engines continued in use, perhaps reduced in size for storage purposes, as maintenance and repair towers. Practically speaking, there was no better machine to employ both in building the Colossus and later in servicing it than the recycled siege towers. With space for many workmen at different heights, internal ladders, openings from bottom to top, rope and pulley machines-- as well as other equipment formerly used to move weapons and ammunition about-- and mobility, their usefulness in construction was just as valuable as in warfare by simply converting everything to peacetime use. There does not appear to be any other engineering tool available to do the necessary outside work at such elevations. There were no standard independently operated cranes so tall. The multi- purpose usefulness of these former war engines could not have been lost on builders of major non-military projects.

The same might be said for the construction of the Colosseum at Rome three centuries later. The Romans used siege craft at Masada in the Jewish Wars. They built the Colosseum and used Jewish slave labor soon after. Why would the Colosseum's architects and engineers not have realized the benefits of employing the same war machines used to defeat the Jews for peaceful reasons within the same decade? Siege towers were certainly superior and more functional than any other piece of construction equipment available. The recently discovered mosaic at the synagogue of Huqoq depicting the use of a giant pulley system to raise large stones for a scene depicting the construction the legendary Tower of Babel ${ }^{34}$

33. Gabriel, La Construction, 338.

34. A photo of the pertinent mosaic may be viewed at, James Rogers, "Stunning Biblical mosaics Revealed in Detail for the First Time," Fox News, November 16, 2018, 
is certainly a boon to our knowledge about standard ancient building techniques. However, the Jews had no knowledge of constructing huge siege towers, the mosaic is from the fifth century A.D., and the simple system depicted would only be useful for assembling lower levels of stone edifices. It never could have served in anything other than an ancillary role in the construction of the Colossus or the Colosseum, both about 160 feet high at their tallest point.

The employment of "siege" towers for large scale construction projects would also help fulfill the comment of Hopkins and Beard about how a "high level of technical and theoretical architectural expertise," into the construction of the Colosseum. Some of the architects and engineers working on the Colosseum had to have been with Titus in Judaea and seen for themselves, if not helped build, the siege engines used there. After they returned to Rome, they would have recognized how easily such mechanical behemoths could be applied to civil construction projects-- as did Chares and the Rhodians while building the Colossus in the immediate aftermath of Demetrius' siege over three centuries earlier.

At 144 feet, the Helepolis was almost as tall as the 160-foot Colossus (with pedestal). We also know that siege towers in operation could be raised, as they had been by the Romans at Masada, as high as they needed to be by moving them upward on earthen ramps. From Marsden's careful calculations, we also know that the base of the Helepolis was an impressive 72 feet by 72 feet. Thus, a 144-foot tower needed a squared base of 72 to insure the necessary stability to keep it upright and effective in battle. Under normal battle circumstances, neither the Helepolis nor other siege towers appear to have had any problem moving or turning on their wheels, demonstrating that their height to base ratio was correctly calculated by their designers. If the same 2-1 formula of height-to-base for the Helepolis is applied to the Colossus, which, while not mobile, was even taller than the 144-foot Helepolis and still needed its weight distributed correctly from its top to its base, the 160-foot statue would have required a pedestal with a base about eighty-feet square in order to remain upright. Based on this scheme, a fifty-foot high pedestal with an eighty-square foot base may be the closest approximation for what was required to support the 110-foot colossal bronze statue of Helios on top of it. Interestingly, at one early stage in Richard Morris Hunt's designs for the Statue of Liberty pedestal, he also used the same ratio whereas its base to height was about twice as high as the width of its base. ${ }^{36}$

Demetrius' Helepolis, of course, was a single construction and moved as a unit, so the weight distribution at its bottom would have been calculated with

https://www.foxnews.com/science/stunning-biblical-mosaics-revealed-in-detail-for-the-fir st-time.

35. Keith Hopkins and Mary Beard, The Colosseum, Wonders of the World, vol. 19 (Cambridge: Harvard University Press, 2005), 142-143.

36. Trachtenberg, The Statue of Liberty, 160. 
that in mind. The Colossus was not a single unit. It was standing on its pedestal, so the weight distribution was divided between the top of the pedestal that held the Colossus and the base of the pedestal, itself. How much difference that would have made, if any, is unclear, but the Helepolis' base had to bear the weight of everything above it, while its multiple stone wheels and axles were still able to be turned with apparent ease. The Colossus's pedestal was firmly joined to the statue, but one would surmise that it would still have had to distribute the weight at its base equally to keep the entire construction stable. Exterior support(s) or column(s), presuming Chares had followed his mentor Lysippus' practice, also helped to steady it.

Although a "single unit," the Helepolis was composed, like the Colossus, of sections built on top of one another and firmly attached to each other by wood and metal. At the height of 144 feet, the construction process used does not appear to have seriously affected the Heliopolis' movement and operation. Because we do not have corresponding details about how the Colossus was held together, we can turn to the method by which the engineers of the Statue of Liberty attached the skeleton of the Statue to its pedestal by joining it to steel beams or girders embedded in the latter that directly tied the two "units" together. It represented a new technology that combined iron and concrete. ${ }^{37}$ Hence, the Statue was literally sealed into the heavy foundation base and permanently fastened to it - rendering it, as noted earlier, a single basic unit in regard to its weight distribution.

Until the nineteenth century, the same type of masonry construction used when the Colossus was built had not changed significantly. With the Statue of Liberty, concrete was also used on a massive scale for the first time, its greatest characteristic being its technologically superior ability, a quantum leap, to strengthen significantly the age-old process of embedding supports within a masonry structure. We have already suggested that a similar system of iron or stone "columns" fastened the Colossus firmly to its base, likewise sealing, as far as the technology of the day allowed, the statue into its heavy stone foundation: The fact that the pedestal and statue had started out separately appears to have made no difference because they were joined so completely that the entire stress would have been borne at the base of the pedestal.

By way of comparison with the Statue of Liberty, her copper base rests (along with her 25-foot feet) on the $40 \times 40$-foot top of an 89-foot pedestal constructed beneath her. That same pedestal at its base is $62 \times 62$ feet, where it is joined to the to the 66-7-foot squared top of the foundation, whose lowest level is below ground and ends in a squared bottom of $91 \times 91$ feet. The final dimensions of the Liberty's bases are, then, from bottom to top, $91 \times 91$ feet, $62 \times 62$ feet, and $40 \times 40$ feet-- and the total height of its foundation and pedestal together is 154 feet. However, the Statue of Liberty, itself, is only 151 feet high, including the extended

37. Ibid. 151. 
torch arm, leaving the measurement of the Statue from heels to head at 111-6 feet, approximately the same height as the Colossus of Rhodes.

Figure 6. The 45-foot pedestal of Agrippa on the stairway to the Propylaea before entering the Athenian Acropolis perhaps provides something of a visual aid for our discussion about the Colossus' pedestal. This pedestal, as seen here, is from the time of Agrippa, whose favor toward the city was rewarded with his representation upon it. However, its history goes back much earlier, and it is thought that a quadriga was originally displayed on it. Without a statue today, most visitors pass right by it, reaffirming our earlier suggestion about how Philo would have paid little attention to the Colossus' pedestal. This pedestal is close in height to the one proposed for the Colossus, though it certainly is not substantial enough to display a 110-foot statue. Nonetheless, its construction still may be instructive. It has a multi-tiered base of about 15-feet, on which a tapering pedestal stretches up another thirty feet, with a plinth at the top to which the statuary was originally attached

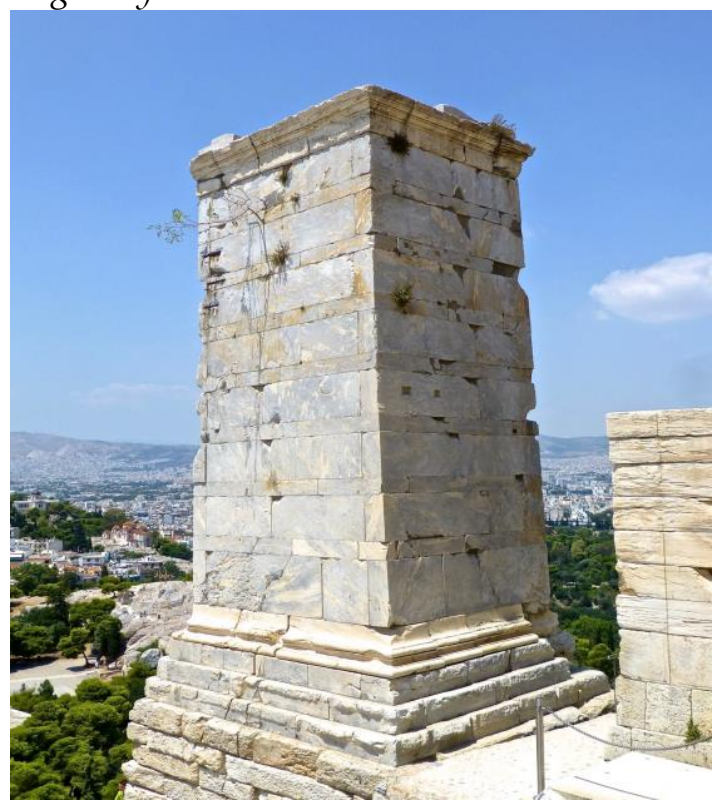

These figures are included for interest-but despite the differences of the two huge display platforms for the Colossus and Liberty in height and the raw materials used in their construction, from what has been proposed here they both end up with bottom bases of about the same dimensions and display colossal statues of about the same size. Engineering problems do not change appreciatively over time, nor do the laws of physics, weight distribution, and the need to adapt a project to the peculiarities of a structure's location. Nonetheless, the aforementioned figures for Liberty may provide an approximate impression of what the proportions may have been at the tops of the three tiers of the Colossus' pedestal as they ascended upward-- and the Statue of Liberty's 25-foot long feet on a $40 \mathrm{x}$ 40-foot base is more than a good indicator since the white marble plinth on which 
the Colossus directly stood similarly had to accommodate its feet, which must have been about the same size.

\section{(c) A Circular Pedestal?}

Finally, there is the lingering tradition that continues to place the Colossus of Rhodes on something of a circular base-- including speculative renderings like Salvador Dali's striking 1954 lithograph of the giant statue. Gabriel believed ${ }^{38}$ that he had found the answer in the small harbor side circular Byzantine fortress of St. Nicholas, which stands at the mouth of Mandraki harbor at the end of the mole at Rhodes-- and the spot where the most famous (but entirely erroneous) depiction of the Colossus bestriding the harbor entrance placed his right foot. Gabriel found stone remains there which he identified as reused from the ruins of the Colossus and discovered enough evidence for a circular base to argue its validity (although this "circular character" is not clearly represented in his Figure 2 above). More recent work suggested that the fortress' core was built on a contemporary classical circular structure of about the same size needed to support a statue the size of the Colossus. ${ }^{39}$ We can never be certain about anything regarding the Colossus, but aside from a few well-known small Greek circular structures at places like Athens, Olympia, Delphi, Epidaurus, and Cnidus, and smaller circular statue bases and pillars, the Greeks did not seem overly interested in large rounded constructions. They certainly posed more problems than the ubiquitous square cornered buildings- and that would definitely have included a pedestal large enough to hold the weight of the Colossus. The ultimate question is about why Chares would have troubled himself to experiment with the round shape-- especially when the Rhodians were refortifying their walls at that very moment and building 50-foot, squared, pedestal-like defensive towers.

Since a lighthouse stands today atop the St. Nicholas fortress' tower on the harbor at Rhodes, it probably would make more sense to interpret what Gabriel and others have found there that might be attributed to a pedestal for the Colossus as the remains of an early lighthouse-- perhaps constructed along the lines of the Pharos lighthouse at Alexandria, whose lower walls also encased a circular interior. Both it and the Colossus were planned/built during the first part of the third century B.C., when the Rhodians and the Ptolemies were especially close and shared ideas about many things - including engineering and architecture. A smaller lighthouse on Rhodes' major commercial harbor is not only likely but probable, even while the Colossus was standing elsewhere above it. Certainly, that is a more logical explanation for whatever the Hellenistic remains are that have been identified at St. Nicholas.

38. Gabriel, La Construction, 347-359.

39. See discussion in Romer, Seven Wonders, 32-33. 
There is also little compelling evidence to suggest that major ancient port cities were accustomed to erecting large colossal statues, whether on square or round bases, at their harbor entrances. We would think Pliny would have mentioned at least one, specifically, in his discussion of colossi (34.18.39-48). He does refer to the 45-foot bronze of Apollo at Apollonia Pontica (see, Figure 4) on the Black Sea but says nothing about it actually standing at the harbor entrance there, where moderns wishing to reconstruct it want to place it. Recent archaeology has shown that it was not at the harbor at all but on an island (modern St. Cyricus) across from the city with its temple. Pliny says little specific about the locations of the Greek colossi about which he speaks other than the names of the cities in which they stood when the Romans carried them off to the capital. His silence may, of course, mean nothing-- but, it could also be because there was little or no Greek practice of placing colossal statues at harbor entrances. Pliny does mention that the Romans failed to move Lysippus' colossal statue of Zeus at Tarentum, a busy port- but he says nothing about that difficulty being caused because the statue was at the harbor entrance. It is more likely that the Greeks looked for more practical locations for their colossi than congested harbor entrances, where they always would have presented difficulties and been in the way. One would certainly think that Athens, at least, a city with well-known colossal statues, would have placed a huge statue of Athena at the entrance to the Piraeus, if it were normal Greek practice to do such things.

Even with the Colossus as the main light tower on top of Monte Smith high above Rhodes City on the acropolis, there would still have been a need for a harbor height lighthouse to guide ships directly into their moorings. That certainly seems a more reasonable explanation because at any given time, there would have been countless ships waiting to dock at one of the greatest ports in the Eastern Mediterranean. The "spillover" must have been tremendous, and it would have extended far outside the designated harbor areas and down the adjacent coasts. Today, there is a lighthouse on top of the old fortress at Mandraki.

There also could have been a large statue of Helios standing on the mole, as Gabriel speculated. None, however, could have been the size of the Colossus, whose complexity and special construction needs were daunting even on the more open grounds atop Monte Smith. To attempt to build such a statue in the center of what was one of the busiest harbor areas in the Mediterranean would not only have been a foolhardy but also an obstruction to sea traffic-- reputedly over a twelve-year period. During this same time, the entire port would have been completely exposed to another attack by Demetrius Poliorcetes or another Macedonian warlord while it was being built. The immediate sea water and effect of the salty sea air on the Colossus' exterior would have made its bronze skin difficult to maintain; corrosion to the more susceptible iron interior frame would have been devastating. Today, 
the same deterioration process is seriously affecting bridge cables and the blades of giant wind towers in salt water locations, requiring constant inspection and maintenance and costing great sums of money. Ship traffic lanes for Rhodes could not have been much different from what they are today. Most ships still depart and arrive from the "blind side" of the main harbor. We would have to accept that Rhodians, many who were not regularly at sea, would have been content to see their Colossus only from its hind side because that would be the main landward view. As shown in the "enhanced" photo in Figure 7, the Colossus could only be seen fully if it did stand atop Monte Smith.

Realistically, it would be very difficult to recommend the placement of the Colossus on a circular, or any other type of pedestal, for that matter, on the harbors at Rhodes. There had never been anything like the Colossus built before and to experiment with it on the water's edge would have been impractical-- and dangerous. Even today with modern skyscraper construction in congested downtown areas, the work, now refined to textbook procedure, still affects for long periods the adjacent businesses, streets, traffic, and pedestrians below.

It is also interesting to note that circular-style designs for the pedestal of the Statue of Liberty-- which, as already seen, was inspired by the Colossus and shares common characteristics with what we know about it-- were discarded early on. At the time of the building of the Liberty, the aura of "The Seven Wonders" was still so much a part of the architectural atmosphere of the day that preliminary designs for its pedestal and foundation base included the "Pharos" series, intended to evoke the cylindrical core and circular upper tier of the Great Lighthouse at Alexandria. The so-called "Pharos Coins" from the Alexandrian mint of Imperial Rome, most produced during the second century A.D., also preserved profile views of the structure that made it look circular-- although the initial plan that the Liberty was also to act as lighthouse (the first American one to use electricity) was probably enough by itself to evoke the popular concept that all lighthouses, ancient or modern, had always been round towers with a light beacon at the top.

The early "Pharos" design of Richard Morris Hunt, one of whose plans for Liberty's pedestal was ultimately selected, was described by Trachtenberg as "a classically rusticated cylinder" 40 and indicates that Hunt was at least trying to keep with the more established, but largely romantic, ideas about what the Pharos Lighthouse had once looked like. His original aspiration for the Liberty may have been a desire, as Trachtenberg also suggests," to combine the Colossus of Rhodes with the Pharos of Alexandria?" ${ }^{41}$ Ultimately, such plans were abandoned in favor of a more practical "squared" pedestal and foundation-tastefully decorated but not so distracting as to diminish the image of Liberty standing upon it. In the case of the Liberty, the final choice was the result of a

40. Trachtenberg, Liberty, 158-159, especially Figures 88 and 90.

41. Ibid., 165. 
number of considerations that were functional, aesthetic, and personal. They did not include a circular pedestal.

Figure 7. Composite photo, illustrating how the Colossus would have been viewed from the harbors at Rhodes, if located atop the acropolis on Monte Smith. Its position there was also ideal to make it the primary lighthouse for Rhodes. (Note: Statue image is the approximate size of the actual Colossus, but its configuration is one of a number of modern speculations). Photo property of author

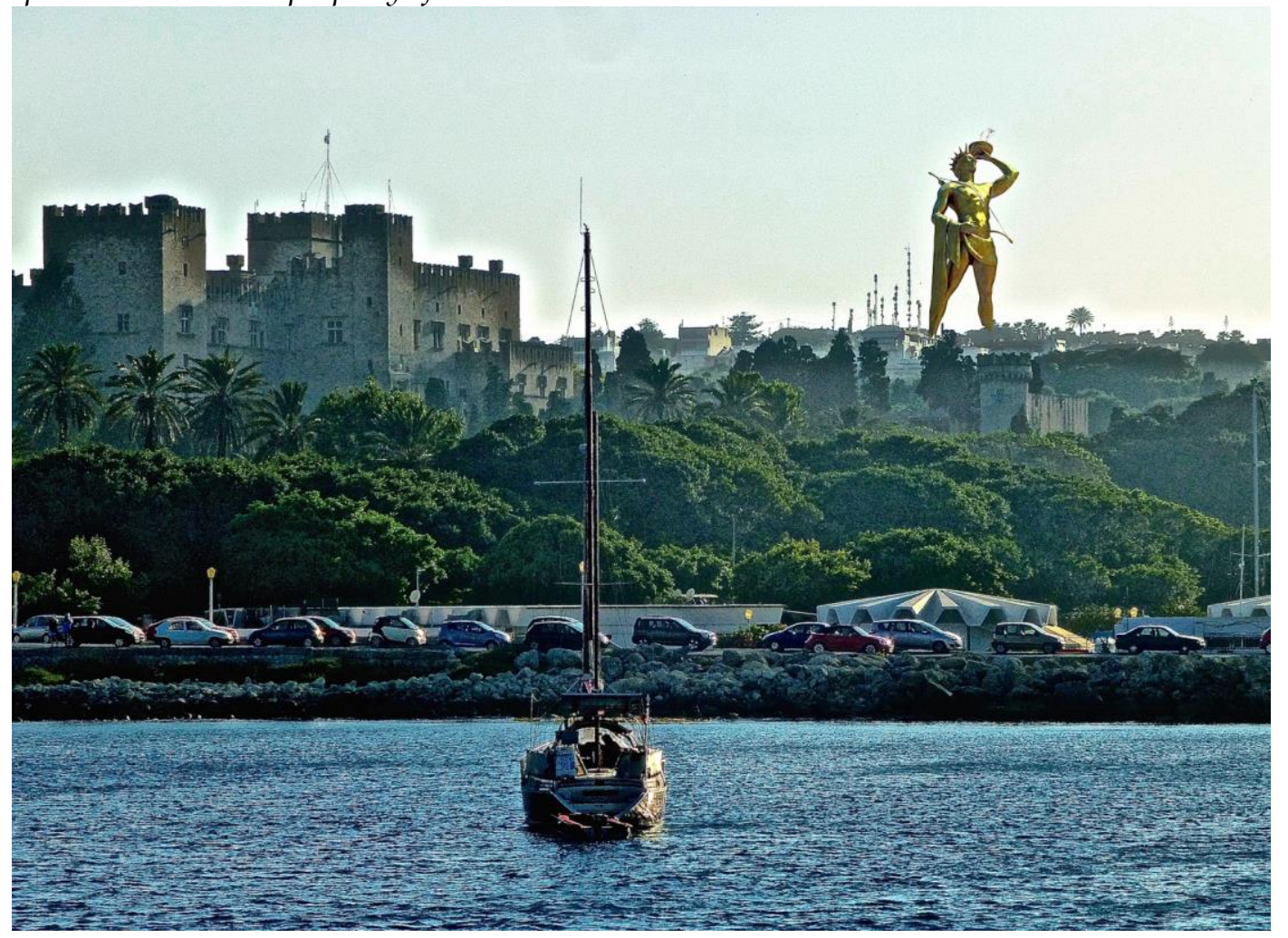

Chares and his colleagues at Rhodes were just as much aware of the problems of a circular rather than squared pedestal supporting the massive weight of the Colossus, which included interior iron work and stones. There already were tall columns with statues mounted on their tops, but to build a "column" so large that it could support something the size of the Colossus was an entirely different proposition. Whether Chares ever experimented with the idea cannot be known, but local masonry construction favored the squared tower construction. The Rhodians were rebuilding their city wall towers at the very same time the Colossus was entering construction. Since that technology was so readily available, there is no reason to suspect that it would not also have been employed in building the pedestal for the Colossus - as if it were another 50-foot squared defensive tower, only tiered.

The short discussion of Rhodes' fortifications in the Grand Palace's archaeological rooms, quotes Aelius Aristides' much later description of the 
towers of Rhodes' walls as looking "straight as candles" from the sea, seeming to suggest that, like the circular towers that are so familiar in the Medieval walls of Rhodes seen today, the towers in Aristides' day were also round. However, Aristides' Rhodian Orations date from four centuries after the Colossus and after Rhodes was devastated in another earthquake in 142 A.D. That makes Aristides' observations useless for our purposes.

The new siege techniques of the Hellenistic period also favored square wall towers. Squared towers had the advantage over round simply because of the additional space in a squared tower. One simply could not allow siege towers to get to the walls. As previously noted, Dionysius I's new fortress of Euryalus at Syracuse, the most siege proof fortress of the day and whose ruins are still impressive, had at least five squared towers, probably as high as 50 feet, the height proposed here for the towers at Rhodes. Catapults and other weapons needed to point at several levels in all directions from which attackers came. Mobile siege towers, the greatest threat of the day, had floors of weapons and were squared. One did not see Demetrius advancing upon the walls and towers of Rhodes in a round siege tower, 144-feet high. The fact that its surfaces were flat-faced also reveals that his siege towers were not designed to attack round towers.

The use of siege tower technology in peacetime construction projects also favors a square shape. Envisioning a 110- foot bronze statue placed on top of a 50foot high "defensive tower" pedestal is certainly more acceptable than a massive circular masonry base. The columns at Karnak in Egypt were about as large as columns were going to get- and a singular unreinforced one to support the weight of the Colossus 50-feet above it would immediately present unwanted problems in stability - especially in earthquake territory.

The most definitive evidence against a circular pedestal for the Colossus perhaps comes from the architectural remains of the Pharos Lighthouse, itself, when it was described by an Arab explorer in the twelfth century. He relates that the base of the Lighthouse had an interior circular core and staircase, but the outside of the building was squared with a sloping incline as it rose up almost 58 meters. The architectural realities seem clear. The inside circular core could not endure standing on its own, and, subsequently, had to be reinforced by building strong masonry walls to reinforce the exterior. If it could not maintain its integrity as an independent circular structure, then neither could a circular pedestal for the Colossus.

Realistic considerations would appear to have eliminated any early ideas about a circular pedestal for the Colossus. Such an idea would certainly have been discarded in its planning stages - just as it was in the case of the Statue of 
Liberty. A tower-like, squared, earthquake proof, three-tiered pedestal was the only sound decision - from both an architectural and engineering standpoint. ${ }^{42}$

\section{Concluding Observations}

Based on the evidence presented, the Colossus of Rhodes was at least 110feet high, was mounted on a three-tier pedestal that was about 50-feet high, whose construction subscribed to the earthquake technology of the day. The dimensions of each tier would accord with how the weight of the statue would have been distributed. The bottom tier compares nicely with that of Demetrius' Heliopolis, which appears to have been close to the ultimate height of the Colossus and pedestal. The 50-foot height for the pedestal also appears appropriate when compared to the walls of Rhodes. The pedestal probably had a core of limestone blocks that was faced with native gray-blue Rhodian marble. At the very top was, as described by Philo, a white marble "base," or more correctly, plinth, in which the soles of the Colossus' feet were firmly embedded. Metal and/or stone reinforcements must have extended through the feet to the statue's knees from the pedestal below and have been anchored securely. Chares probably provided, as his master, Lysippus, had for his 60foot colossus statue of Zeus at Tarentum, an additional anchoring "column(s)" of some appropriate design to further stabilize the Colossus. Whether it was built into the pedestal or was a short distance from the statue, it failed, too, to hold the Colossus erect during the fatal earthquake.

42. Interesting to the discussion, nonetheless, is a circular building standing on Monte Smith today, not far from its summit and in the vicinity of where we place the actual location for the Colossus. Although its diameter looks to be only about 30 feet, World War II reconnaissance photos show it to be existing at that time. What is was, what it is, what was (and is) inside it, and what lies underneath it is anyone's guess-- impossible to know because it is now off limits, covered with protective wire, and closed to the public. I include a photo of it below (Figure 8) only for interest's sake, if anyone wishes to pursue it further. 
Figure 8. The Circular Building near The Summit of Monte Smith, Above Rhodes City

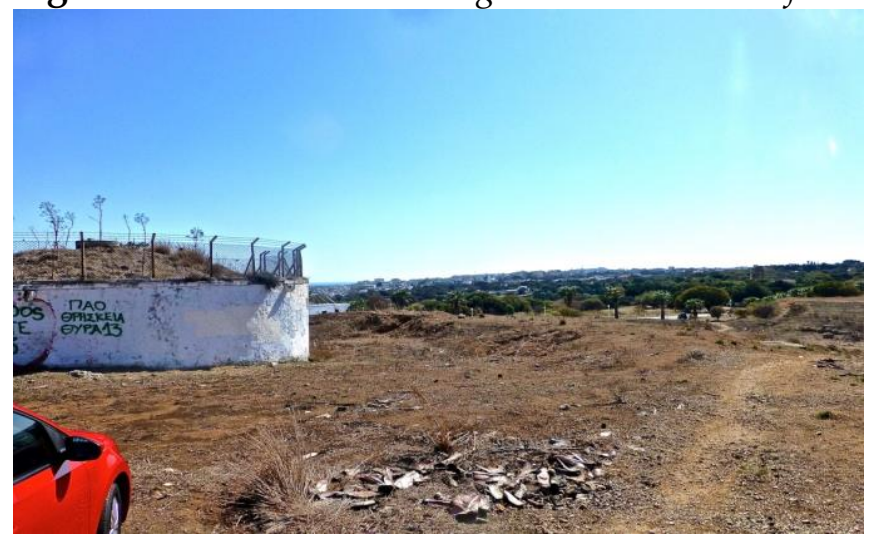

\section{Bibliography}

Albertson, Fred C. "Zenodrous's 'Colossus of Nero."' In Memoirs of the American Academy in Rome, edited by Anthony Corbeill, 46: 95-118. The University of Michigan Press, 2001.

Austin, C., and Bastianini, G. Posidippi Pellaei Quae Supersunt Omnia. Milan: LED (Edizioni Universitarie di Lettere Economia Diritto), 2002.

Bayraktar, A., Keypour, H., and Naderzadeh, A. "Application of Ancient Earthquake Resistant Method in Modern Construction Technology". In Proceedings of the 15 WCEEE, Lisbon. Portuguese Society of Seismic Engineering -SPES, 2012. 38: 3070930718. https://www.iitk.ac.in/nicee/wcee/article/WCEE2012_5773.pdf.

Caldwell, Thomas Francis. "The Career of Licinius Mucianus." Master's Thesis, University of Melbourne, 2015. https://minerva-access.unimelb.edu.au/bitstream/handle/11343/ 91093/Thomas_Caldwell_MA_Thesis.pdf?sequence $=1 \&$ isAllowed $=\mathrm{y}$.

Connolly, Peter. Greece and Rome at War. 1981. Reprint, London: Green Hill Books, 1998.

Dale, Alexander. "Lyric Epigrams in Meleager's Garland, the Anthologia Palatina, and the Anthologia Planudea." Greek Roman \& Byzantine Studies (GRBS), no. 50 (2010): 193213. https://grbs.library.duke.edu/article/viewFile/1461/1551.

Dickie, Matthew W. "What Is a Kolossos and How Were Kolossoi Made in the Hellenistic Period?" Greek Roman \& Byzantine Studies (GRBS), vol. 37 (1996): 237-257. https://grbs. library.duke.edu/article/viewFile/2801/5855.

Dikov, Ivan. "Bulgaria's Sozopol to Restore Ancient Statue of Apollo, 'Colossus of Apollonia Pontica', Not Unlike Greece's Plans to Rebuild Colossus of Rhodes." Archaeology in Bulgaria (portal), January 5, 2016, http://archaeologyinbulgaria.com/20 16/01/05/bulgarias-sozopol-to-restore-ancient-statue-of-apollo-colossus-of-apolloniapontica-not-unlike-greeces-plans-to-rebuild-colossus-of-rhodes/.

Gabriel, Albert. "La Construction, L'Attitude et L'Emplacement du Colosse de Rhodes (The Construction, Attitude and Location of the Colossus of Rhodes)." Bulletin de Correspondance Hellénique, no. 56 (1932): 331 - 359.

Gow, A.S.F., and Page, D.L. The Greek Anthology: Hellenistic Epigrams. Cambridge: University Press, 1965. 
Higgins, Reynold. "The Colossus of Rhodes." In The Seven Wonders of the Ancient World, edited by Peter A Clayton \& Martin Price, New York: Barnes \& Noble, 1993.

Hopkins, Keith, and Beard, Mary. The Colosseum. Wonders of the World, vol. 19. Cambridge: Harvard University Press, 2005.

Kebric, Robert B. "Lighting the Colossus of Rhodes: A Beacon by Day and Night." Athens Journal of Mediterranean Studies 5, no.1 (January 2019): 11-31. https://www. athensjournals.gr/mediterranean/2019-5-1-2-Kebric.pdf.

Kebric, Robert B. “The Colossus of Rhodes: Some Observations about Its Location." Athens Journal of History (forthcoming), [2019].

Lucian of Samosata. "Tragopodagra." In Selected Satires of Lucian, edited and translated by Lionel Casson. New York: Norton Library, 1968.

Marsden, E.W. Greek and Roman Artillery: Technical Treatise. Oxford: Oxford University Press, 1969. Reprint, 1999.

Maryon, Herbert. “The Colossus of Rhodes." The Journal of Hellenic Studies, Vol. 76 (1956): 68-86.

Pliny, Natural History. Edited and translated by H. Rackham. Loeb Classical Library. Cambridge, Mass.: Harvard University Press, 1952. Reprint, 1995.

Rogers, James. "Stunning Biblical Mosaics Revealed in Detail for the First Time." Fox News, November 16, 2018, https://www.foxnews.com/science/stunning-biblical-mo saics-revealed-in-detail-for-the-first-time.

Romer, John, and Romer, Elizabeth. The Seven Wonders of the World: A History of the Modern Imagination. London: Seven Dials, Cassell \& Co., 1995.

Strabo, The Geography of Strabo. Edited and translated by Leonard Horace Jones. Loeb Classical Library. Cambridge, Mass.: Harvard University Press, 1960. https://archive. org/details/Strabo08Geography17AndIndex.

Trachtenberg, Marvin. The Statue of Liberty. New York: Viking Press, 1976.

Vedder, Ursula. "Was the Colossus of Rhodes Cast in Courses or in Large Sections?" In Artistry in Bronze: The Greeks and Their Legacy: XIX International Congress on Ancient Bronzes, edited by Jens M. Daehner et.al., 21-27. Los Angeles: The J. Paul Getty Museum and the Getty Conservation Institute, 2017. http://www.getty.edu/publicati ons/artistryinbronze/downloads/DaehnerLapatinSpinelli_ArtistryinBronze.pdf. 